Article

\title{
Evaluating the Relationship between Park Features and Ecotherapeutic Environment: A Comparative Study of Two Parks in Istanbul, Beylikdüzü
}

\author{
Didem Kara ${ }^{1, *(1)}$ and Gülden Demet Oruç ${ }^{2}$ (I) \\ 1 Urban Design Master Program, School of Engineering, Science and Technology, \\ Istanbul Technical University, Istanbul 34469, Turkey \\ 2 Urban and Regional Planning Department, Faculty of Architecture, Istanbul Technical University, \\ Istanbul 34437, Turkey; orucd@itu.edu.tr \\ * Correspondence: karadi@itu.edu.tr; Tel.: +90-5534-921-003
}

Citation: Kara, D.; Oruç, G.D.

Evaluating the Relationship between Park Features and Ecotherapeutic Environment: A Comparative Study of Two Parks in Istanbul, Beylikdüzü. Sustainability 2021, 13, 4600. https:// doi.org/10.3390/su13094600

Academic Editor: Israa H. Mahmoud

Received: 24 February 2021

Accepted: 12 April 2021

Published: 21 April 2021

Publisher's Note: MDPI stays neutral with regard to jurisdictional claims in published maps and institutional affiliations.

Copyright: (c) 2021 by the authors. Licensee MDPI, Basel, Switzerland. This article is an open access article distributed under the terms and conditions of the Creative Commons Attribution (CC BY) license (https:// creativecommons.org/licenses/by/ $4.0 /)$.

\begin{abstract}
The impacts of problems related to dense, unplanned, and irregular urbanization on the natural environment, urban areas, and humankind have been discussed in many disciplines for decades. Because of the circular relationship between humans and their environment, human health and psychology have become both agents and patients in interactions with nature. The field of ecopsychology investigates within this reciprocal context the relationship between human psychology and ecological issues and the roles of human psychology and society in environmental problems based on deteriorated nature-human relationships in urbanized areas. This approach has given rise to ecotherapy, which takes a systemic approach to repairing this disturbed naturehuman relationship. This study aims to uncover the relationship between the physical attributes of urban green areas and their potential for providing ecotherapy service to users, first by determining the characteristics of ecotherapeutic urban space and urban green areas given in studies in the ecopsychology and ecotherapy literature, and then by conducting a case study in two urban parks from the Beylikdüzü District of the Istanbul Metropolitan Area. The impacts of these parks' changing physical characteristics on user experiences are determined through a comparison of their physical attributes and the user experiences related to their ecotherapy services.
\end{abstract}

Keywords: greening cities; urban design; ecopsychology; ecotherapy

\section{Introduction}

There has always been a bidirectional relationship between humankind and its environment. While humanity changes the environment based on its needs, the environment has in turn played an essential role in human evolution and development. Urban areas are one of the best examples of anthropogenic impacts on the environment. Such places are structured based on human needs and lifestyles under the influence of other anthropogenic factors such as industrialization, population growth, migration, development levels, and national policies. The phenomena born of these factors, such as rapid and distorted urbanization, have negatively affected natural areas and resources, leading to the creation of problematic and substandard urban areas. Moreover, the establishment of unplanned urban areas has resulted in both direct and indirect harm upon their inhabitants [1].

The indirect impacts of these areas are felt mostly in the natural environments that provide vital services for human life, resulting in shortages of environmental resources, the destruction of necessary ecosystems, the loss of biodiversity, and rises in global warming and pollution [2]. The direct impacts involve the damage caused by these urban areas to people's physical and mental health, e.g., diseases that can spread quickly in dense urban areas with poor physical conditions and a lack of infrastructure [3-8], lifestyle-related illnesses $[3,4,6,9,10]$ resulting from the lack of physical activity and unhealthy dietary 
habits and food provision in some urban areas, afflictions related to exposure to urban pollution $[3-6,8,9]$, and, lastly, mental issues caused by urban features such as the lack of social infrastructure [11], poor physical conditions, pollution [3,4,8,11-13], high population densities, and overcrowding $[3,4,8,12,13]$.

The role of environmental sciences in solving the problems above has become more prominent; however, world ecosystems and human populations are still facing constant ecological issues. Considering the importance of individual behavior and awareness, there is a need for systemic (and comprehensive) approaches and solutions in terms of the reconstruction of individuals' relationship with nature and the environment. In this way the outputs of the social sciences examining human-nature relationships may offer valuable inputs for the urban planning and design disciplines. Environmental psychology stands out for this purpose, as it has been examining since the 1960s the bidirectional relationship between humans and the environment, its focus ranging from the physical and social effects of urban space to the impacts of natural areas on human psychology. Moreover, discussions on sustainability have included the claim that environmental psychology has evolved as a "psychology of sustainability" [14].

First coined by Theodore Roszak in 1992, ecopsychology has helped to develop environmental awareness and change behavior toward ecological problems through examination of the relationship between the environmental issues and human spiritual or psychological ones. Roszak argued that human activities and economic systems have changed, detailing the harmful effects of this changing activity and economic order on the ecosystem. Roszak noted that disconnection from nature and other people due to urbanization both increases negative impacts on the environment and deepens psychological problems [15]. To this end, the field examines the roles of human psychology and society in environmental issues within the framework of the deteriorated nature-human relationship [16].

In his treatment of the relationship between people and the environment, Scull posited a more experiential role for ecopsychology in theory and practice, asserting that many things can be learned through contact with nature [16]. This approach is speculative, philosophical, and theoretical, preparing a basis for the reconstruction of the naturehuman relationship with a new language and model; it may also have a role to play in environmental protection and in solving human psychological problems through the adoption of practices such as environmental activism and ecotherapy.

At this point, it is clear that ecopsychology offers a solution to the problems of urbanization and urban areas based on the individual's perspective of and connectedness to nature (CNS). In addition to Scull's approach, through which strong ties are established to fields such as deep ecology and environmental activism, ecotherapy studies have introduced a systemic therapy method for repairing the disturbed nature-human relationship. Clinebell defined ecotherapy as "recovery and growth with a healthy relationship with the world" [17], using it as an inclusive term in the context of nature-based physical and psychological recovery methods. This approach to ecotherapy deals with psychotherapy and psychiatry in the context of nature and nature-human relationships. Clinebell labeled ecological deterioration the most profound health issue of all time owing to the vital role of ecosystems in the continuity of our kind and offered as a solution to this problem the raising of awareness about lifestyles through ecotherapy and early childhood eco-education [17].

Ecotherapy thus may offer a help to solve environmental problems and the psychological issues caused by disconnection from nature. Ecotherapeutic studies are based on a three-phased process: (1) acknowledgment of the healing presence of nature, (2) recognition of more-than-human experiences and self-relocation in the natural world, and (3) the sharing of this experience with other people and involvement in activities that care for the planet [17]. Ecotherapy is the name given to a wide range of programs aiming to improve mental and physical health through activities in natural areas and connection to nature. These activities include working in or experiencing nature [18]. However, the fulfillment 
of this reconnection is conditional on spending time and being active in natural areas and making these activities a part of daily life.

It is thus essential to be in nature and understand that being a part of the ecosystem is vital to solving both physical and mental health problems as well as to help the environmental crisis. Accordingly, ecotherapy helps people to recognize nature, appreciate it more, and be respectful to the earth. The necessity of addressing this approach through spatial studies has arisen from an emphasis on the importance of natural areas and spending time in nature, as issues related to disconnection from nature occur most frequently in urban spaces where natural areas and elements are scarce. Natural areas and urban greeneries have been subjects for examination in environmental disciplines for many decades because of their services to humans, their recreational functions, and their importance to urban quality and ecosystems $[19,20]$. Studies have investigated the benefits of these qualities for mental and physical health, in particular, their role in encouraging people to do physical exercise $[21,22]$. However, apart from their impacts on overall health, spatial studies have focused on the role of ecopsychology and ecotherapy to help people to be aware of environmental problems. For this purpose, it is helpful to understand their therapy functions for citizens in addition to their impacts on the quality of urban areas. The design of urban green spaces should be reviewed based on the features of therapeutic environments that create environmentally conscious individuals who can address the source of their health problems and environmental problems.

This study aims to reveal the relationship between the physical attributes of the urban green areas and their potential for providing ecotherapy service to citizens. The first section contains a brief explanation of the aspects of ecotherapeutic environments, determining the characteristics of ecotherapeutic urban spaces and urban green areas through an examination of the benefits obtained from green or natural places, their effects on human psychology, the attributes of therapeutic areas, and the types of therapeutic activities. These have been classified by discourse analysis in accordance with their contribution to the urban design process. In determining the attributions above, literature research was conducted in the Scopus' database in August 2019. A total of 249 papers were found in the database with the "ecopsychology" keyword and 57 with the "ecotherapy" keyword. Out of these articles, those related to psychology, social sciences, and environmental sciences were filtered, and 37 articles remained to be examined. The findings of this literature review were presented in detail at the 28th Symposium of Urban Design and Implementations and published as an article in the Design+Theory Journal in Turkish [1].

The second part of the study examines two parks from the Beylikdüzü District of the Istanbul Metropolitan Area in order to compare the impressions of the results obtained from a literature review of space and user experience. This comparison is twofold: (1) physical characteristics and (2) user experience. The physical characteristics of the parks are analyzed and presented via several maps, satellite images, diagrams and pictures. Data concerning user experience were obtained through a survey conducted with the users of these parks. This study adds to the ecopsychology literature by evaluating the ecotherapeutic benefits of green spaces and how these differ according to the urban design principles adopted when designing the spaces. In addition to highlighting the ecological and recreational benefits of urban green spaces, this study provides guidance for planning and designing green areas with improved ecotherapeutic features that may further enhance the psychological health and environmental awareness of city residents.

\section{Characteristics of Ecotherapeutic Environment}

The characteristics of ecotherapeutic environments and their effects on human psychology can be evaluated according to ecotherapeutic activities, type, benefits and features of ecotherapeutic environments. Ecotherapeutic activities are examined within two categories: working in nature and experiencing nature. Working in nature includes various athletic activities defined as the green and blue gym [23-29], the most significant of which is walking [23-26,30-35]. Apart from athletics, this group comprises activities such as 
meditation/therapy $[23,25,28,33,34,36,37]$, art $[28,38,39]$, and production in/with nature (frequently gardening and horticulture) [36,38]. Experiencing nature involves spending time observing and listening in nature $[23,26,28-30,32,36,38]$. Activities from both groups can be conducted in natural areas to obtain ecotherapy services, and an understanding of these activities allows designers to provide proper facilities or places to citizens in these areas.

The types of ecotherapeutic environments are grouped according to their location in inner, peripheral, and outer urban areas. Ecotherapeutic areas located on the outer and peripheral parts of an urban area include various natural areas and landscapes, of which forests $[23,24,30,31,40-43]$ and wilderness areas $[23,25,32,36,44,45]$ are the most prominent types. Ecotherapeutic areas located in inner urban areas include many public and private green areas; urban parks [24-26,30-33,36,38,41-43,46,47] and private gardens $[23,26,36,43,48-50]$ are the most prominent examples of this type. These results reveal the need for natural spaces and urban greeneries in the urban texture because of their ecotherapy benefits. Moreover, they underline the importance of providing and protecting these areas both within and outside of the urban texture. Knowledge of the types of ecotherapeutic areas can help planners and designers consider these areas in their spatial decisions.

The benefits of therapeutic environments on human psychology comprise two categories: (1) mental and emotional benefits and (2) advancement in self-placement and perception. The most prominent mental and emotional benefits are relaxation $[24,26,27,36,51]$, improvement in attention $[24,28,30,34,39,41,48,52]$, concentration $[26,31,34,53]$, and $\operatorname{mood}[23,26,29,34,48,51]$, and declines in stress [23,24,26,28-31,33,34,36,43,48,51,52], anxiety, depression $[25,28,30,33,39,48]$, and anger [39,41]; better self-esteem is the most prominent manifestation of advancement in self-placement and perception [25-28,34,39,48,54]. These results demonstrate that spending time in natural areas helps people to cope with mental problems and gains importance in tandem with the growing negative impacts of urban areas on human mental health. Ecotherapy services increase the quality of life of citizens. Recognizing these benefits offers a new perspective for urban studies and design practices, especially in terms of designing cities and their green areas in a way that will provide ecotherapy services.

The features of ecotherapeutic areas, which can serve as the most directing outputs to environmental designers, are grouped into the categories of accessibility and size, design features, the fauna of therapeutic areas, and the sensations the areas create. First, as mentioned above, spending time in nature daily is essential in the provision of ecotherapy services. So the accessibility [34,36], inner circulation [39], and size [36,55] of these areas should be suitable for the daily use of citizens in their activities. The second group, design features, includes subgroups such as vegetation and natural elements, facilities and furniture, physical environmental control (daylight, wind, etc.), inner view and perception, and relationship with surrounding urban space. Vegetation and natural elements consists of the existence of landscapes and green areas with trees [29,30,32,36,45,55], bushes [26,30,55], grass [55], and flowers [24], and their type [30], density [31,42,56], and diversity [42,50]. Natural and artificial water elements $[24,26,30,32,36,41,45]$ are evaluated under this subgroup. The facilities and furniture subgroup involves, rather than specific facility or furniture types, the compatibility of the furniture materials $[26,55]$ with the natural characteristics of the area. It also includes certain exercise equipment [26] that encourages people to be more active. The inner view and perception subgroup comprises the necessity of structuring depth, complexity, enclosure, and vegetation density, each in a well-balanced manner, allowing for open views and remote landscapes [42,56]. Moreover, the visual relationship between ecotherapeutic areas and urban texture is a critical part of providing pristine and more natural perception $[36,50]$ in an area. Consequently, it is better to obscure visibility of the urban pattern from ecotherapeutic areas [56] and increase the visibility of these areas from urban spaces $[45,50]$ through regulations such as those that limit the number of floors in new buildings, lower urban density around green spaces [32,57], and create mild 
transitions from parks to urban areas [56]. Additionally, the presence of fauna enhances the natural image of the area, and encounters with wild animals and hearing animal sounds (bird sound, etc.) increase therapy service [26,29,31,41,45,53]. Lastly, ecotherapeutic areas create sensations helpful in obtaining therapy services such as peacefulness $[41,58]$, quiet [26], solitude, distance [55], aesthetic pleasure [26], beauty [26,41], and fascination [35]. In order to obtain ecotherapy services as they are defined, people require the presence of sensations that oppose those endemic to dense urban areas such as overcrowding, noise pollution, etc. Natural elements and characteristics have thus become prominent in the design of therapeutic areas.

\section{Method}

The methodology of the study was twofold: examining the spatial characteristics of selected urban parks and examining the change of user experience according to the features of the parks. For the spatial examination of selected parks, the characteristics of the surrounding urban fabric and demographic structure of the population they serve were kept constant for the purpose of comparing their internal characteristics and the relationships they established with the surrounding urban fabric. Accordingly, two parks located close to each other were selected for the examination. The study also compared the different features of these two parks, such as type, size, form, design, and vegetation. A detailed examination of vegetation was conducted for this study with the help of site observation, 28 videos and 691 photographs that have geo-positioning data.

In order to evaluate user experience, a survey was conducted in the selected urban parks (Table S1). The first section of the survey contained a scale measurement of "connectedness to nature" to gauge individuals' effective and experiential connection to nature [59]. The scale was developed for the empirical studies on the basis of Leopold's claim that the environmental awareness depends on the feeling of belonging to the wider natural world [60]. Dependently, CNS included 14 questions about one's perspective of being a member of the natural world, feeling a sense of kinship with it, seeing themselves as belonging to the natural world as much as it belongs to them, and considering that their welfare depends on the welfare of natural world [59]. It was developed as a 5-point Likert scale, and scores were calculated as a mean value of the answers. CNS was selected, first, to seek out a relationship between the frequency of time spent in selected urban parks and consciousness about the value of the natural environment, and, second, to determine a relationship between the user profile regarding connectedness to nature and ecotherapy service. An understanding of user profile relation to environmental issues and connectedness to nature was essential in revealing whether or not the ecotherapy service provided by the city parks was available regardless of the user profile and ecological consciousness.

The second section of the survey consisted of 5-point Likert scales and open-ended questions about the features, activities, and feelings highlighted in ecopsychology and ecotherapy literature. The section made inquiries concerning types of activities, the adequateness of the parks for users, the impact of park characteristics on park preference, satisfaction with park characteristics, the influence of interior and exterior features or factors on the natural image of the parks, the relationship with the surrounding urban area, and the emotions/mental states that participants experienced during park use.

The survey was conducted in two selected parks at the same time, on four days from 12-15 September 2020 (two days during the week and two days on the weekend) from 8 a.m. to 8 p.m. Participants were chosen randomly within the two parks. The researchers first introduced themselves, informed the participant about the study, and the participant's consent was obtained for conducting the survey. A total of 90 subjects ( 49 male, 41 female) participated in the survey, 45 from each park. As the data on the total daily users of the park were unavailable, the decision on minimum sample size was based on the Central Limit Theorem, which defines the accurate sample size as more than 30. Besides, according to the calculations made on the population of the neighborhoods surrounding the parks, the ideal sample size was found to be 96 people, yet the sample was limited to 90 people in 
total because the proposed park users did not volunteer to participate in the survey during the pandemic.

\section{Case Study}

The history of the Istanbul Metropolitan Area goes back to the ancient settlements of 7-8 thousand years ago. It is a city that later became the capital city of important empires such as the Byzantine and Ottoman. The most important period of time that changed the face of the city took place in the Republic period. With the industrialization process, migration from rural to urban areas and rapid urbanization have taken place since the 1950s; the city has begun to sprawl and lose the important natural and green areas [61,62]. The development direction of the city shifted from the east-west direction to the north where the forests and other natural areas are rich, after the construction of the bridges over the Bosporus. In addition, due to the increased accessibility and uncontrolled urbanization, the historical core has become denser in time [62]. Today, with its diverse cultural and historical layers and over 15 million inhabitants, Istanbul is the biggest metropolitan area of Turkey [63]. Beylikdüzü District, where selected urban parks are located, is a newly urbanized settlement in comparison to the history of the city. Urban development of the district was pioneered by the housing cooperatives in 1990s [64]. This district was selected for the case study due to the presence of green areas of various sizes and shapes in the similar urban pattern, for an accurate comparison.

In the case study, two parks were selected to help gauge the relationship between spatial features and user experience. The first of these parks is a linear park system consisting of the Fatih Sultan Mehmet (FSM) and Mehmet Akif Ersoy (MAE) Woods, and the other is the Municipality Park (Figure 1).

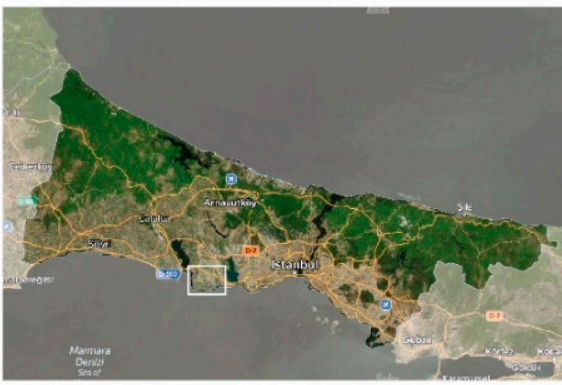

(a)

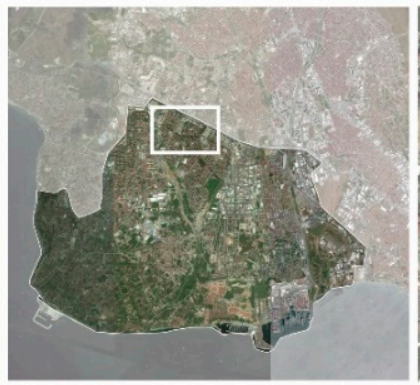

(b)

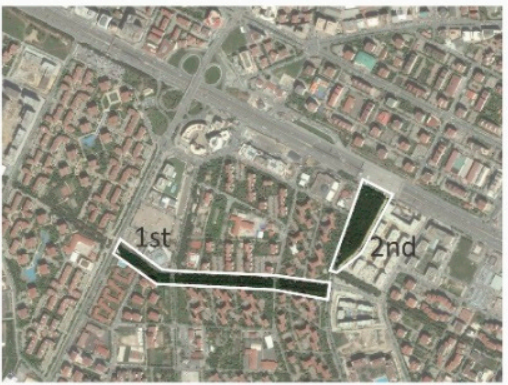

(c)

Figure 1. (a) Location of the Beylikdüzü District in Istanbul; (b) Location of selected parks in Beylikdüzü District; (c) Location of parks (Figure is produces by researchers. Source: Yandex Maps Satellite Image, date: 15 May 2018, accessed on 15 December 2020 [65]).

Spatial Analysis/Characteristics of Fatih Sultan Mehmet (FSM) and Mehmet Akif Ersoy (MAE) Woods and Municipality Park

The FSM and MAE Woods are located between a street and a residential dwelling unit. The total length of the park system is $702 \mathrm{~m}$, and its width varies from 16 to $25 \mathrm{~m}$ (see Figure 2). It has a surface area of 15,000 square meters. On the other hand, Municipality Park, located at the eastern end of the MAE Woods, is a vaguely triangular-shaped park $285 \mathrm{~m}$ in length and with a 14,107 square meter surface area. The park is adjacent to an urban square designed for pedestrian passage above the E-5 highway (Figure 2). 


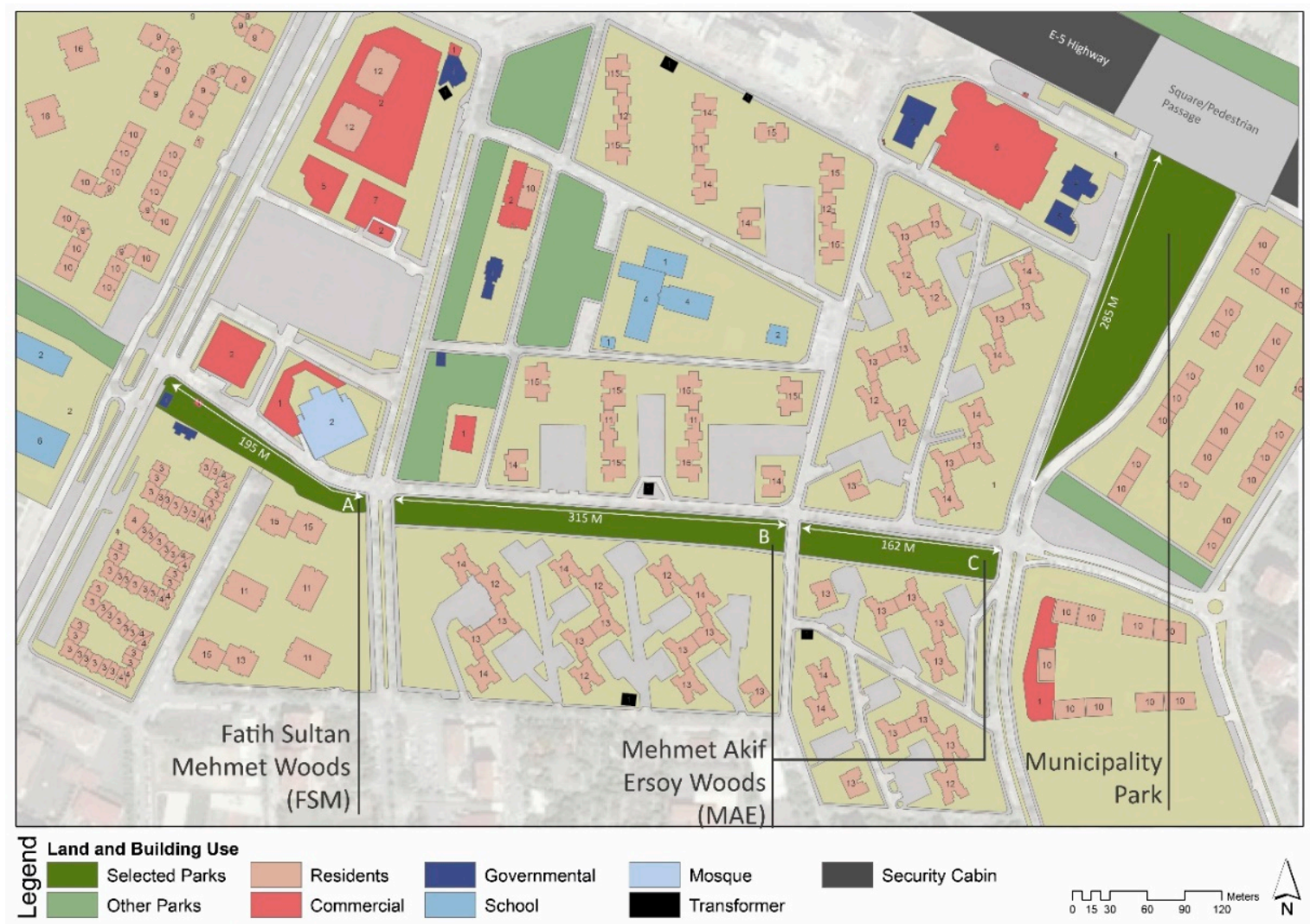

Figure 2. Land uses and no. of building floors in the surrounding urban area (reproduced by researchers from the Municipality Base Map [66]).

These parks and the surrounding urban area have a nearly flat topography, which provides easy access and mobility for pedestrians. The land uses of the surrounding urban area consist mostly of highly populated and gated residential dwelling units and a few large facilities such as mosques, schools, and malls. While of the number of floors in facilities like schools and mosques varies from one to six, nearby residential buildings generally have a higher number, ranging from four to 16 (Figure 2).

While the vegetation of both parks consists mainly of evergreen trees such as the Lawson cypress, palm tree, and nut, black, and Tenasserim pine, there are some deciduous trees such as the common ash, Norway maple, horse chestnut, acacia and plum. As shown in Figure 3, crown closure of the canopy is very high due to the density of the trees in both parks. Because of the prominence of evergreens, these parks have a very closed and forest-like atmosphere in every season (Figure 3).

The distribution of trees and bushes shows that all sections have different characteristics. The bushes and shrubs were evaluated based on density and length (Figure 4). Sparse and short in other sections, bushes and shrubs are dense in the FSM Wood (Figure 5). In the Municipality Park, there is a high plant variety in both trees and bushes, with three vegetation layers consisting of the tallest pine trees at the top, various deciduous trees of relatively shorter height in the middle, and various bushes, shrubs and annual wild plants on the floor. Along the eastern border, the park is separated from the road by a wall of Lawson cypresses. On the western edge, various other tall and medium-height bushes and shrubs act as separators. The density of bushes and shrubs becomes higher and more irregular in the inner part of the park and decreases in the southern region (Figure 6). There are no planted flowers, grass-covered surfaces, or wide-open spaces in either of the parks. 


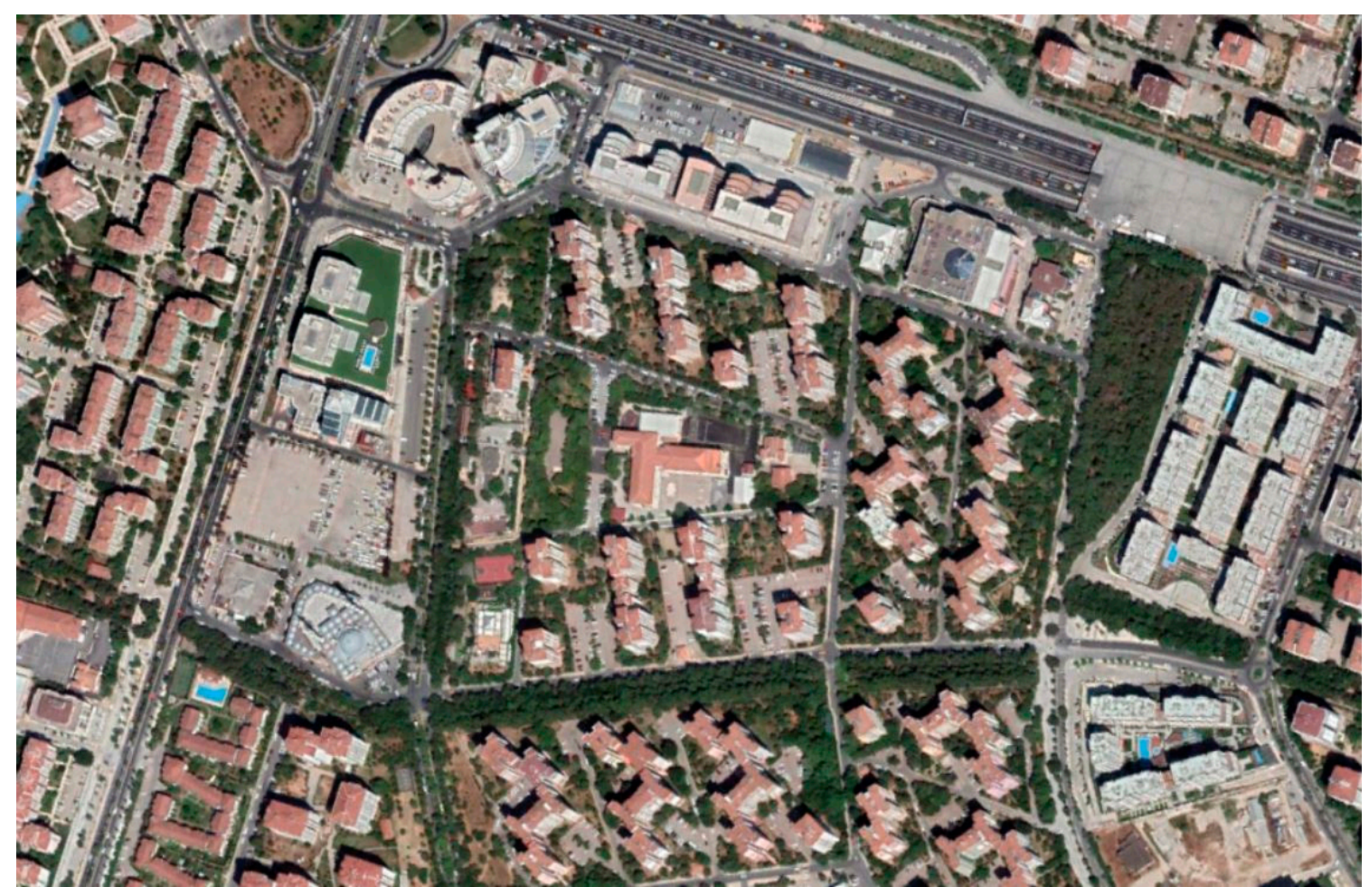

Figure 3. Satellite image of the parks showing the crown closure (Source: Google Earth Satellite Image, date: 08 December 2020, accessed on 08 April 2021 [67]).

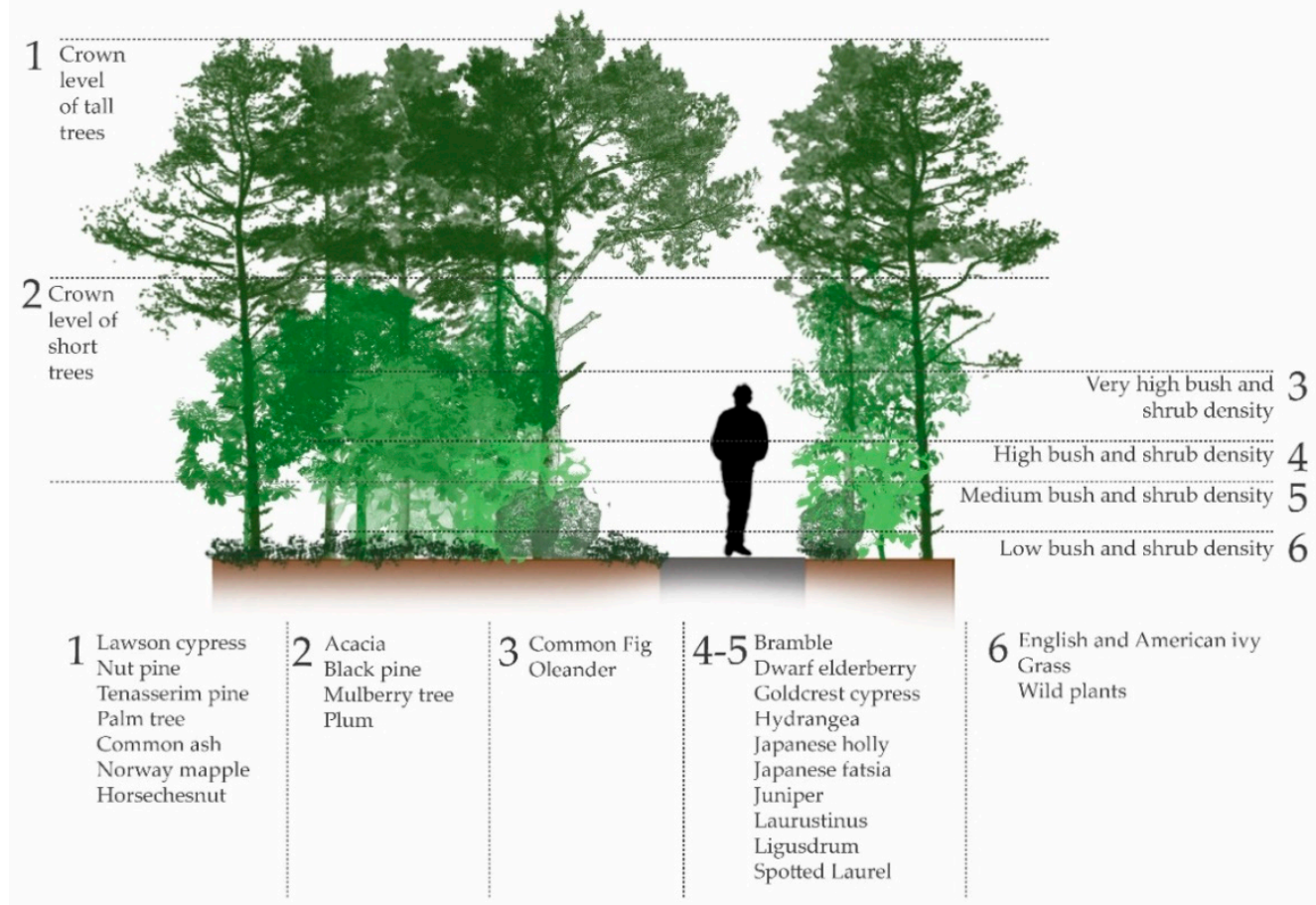

Figure 4. Height and density of trees, bushes, and shrubs. 


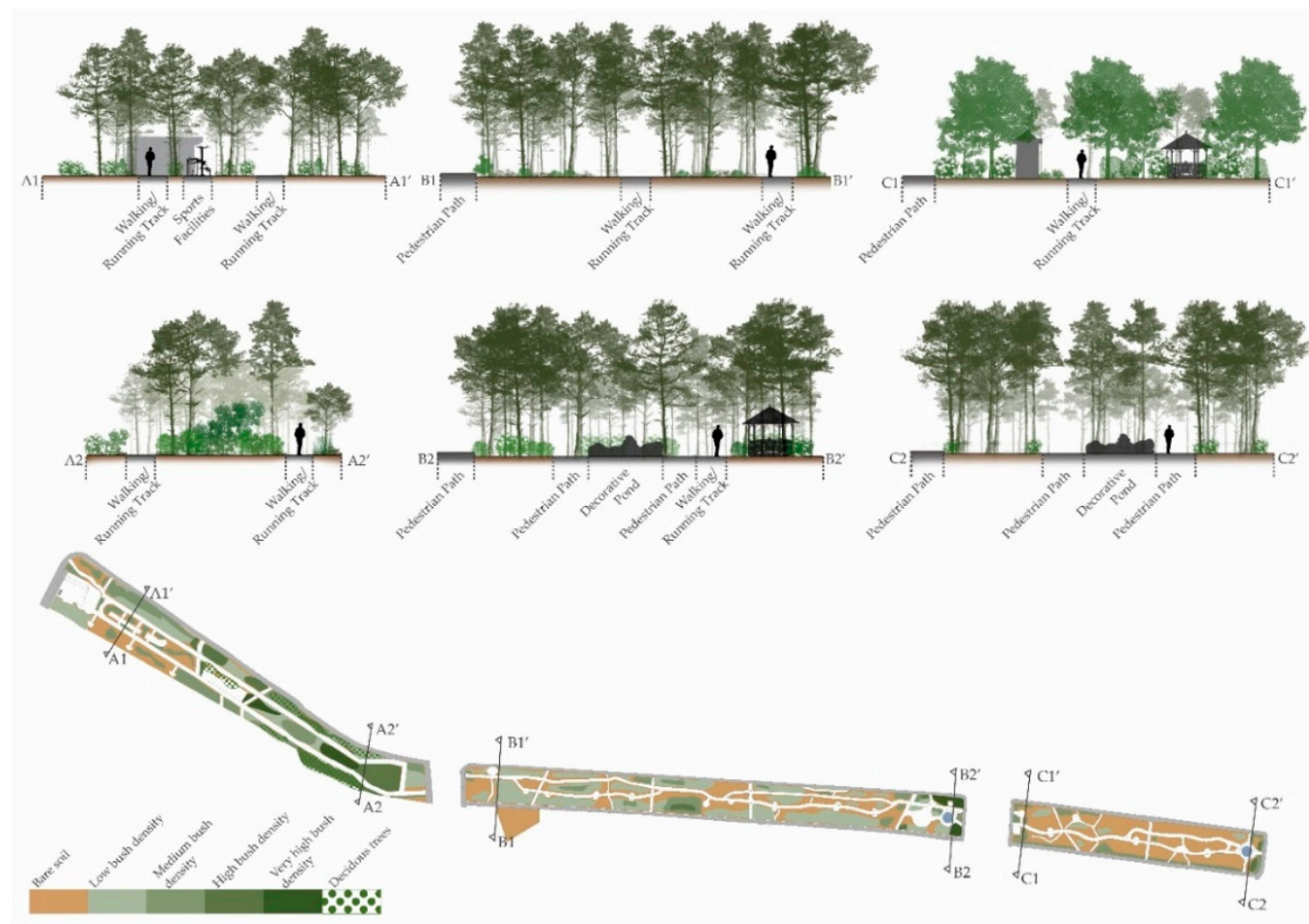

Figure 5. Height and density of trees, bushes, and shrubs in the FSM and MAE Woods (reproduced by researchers based on the Municipality Base Map [66]).
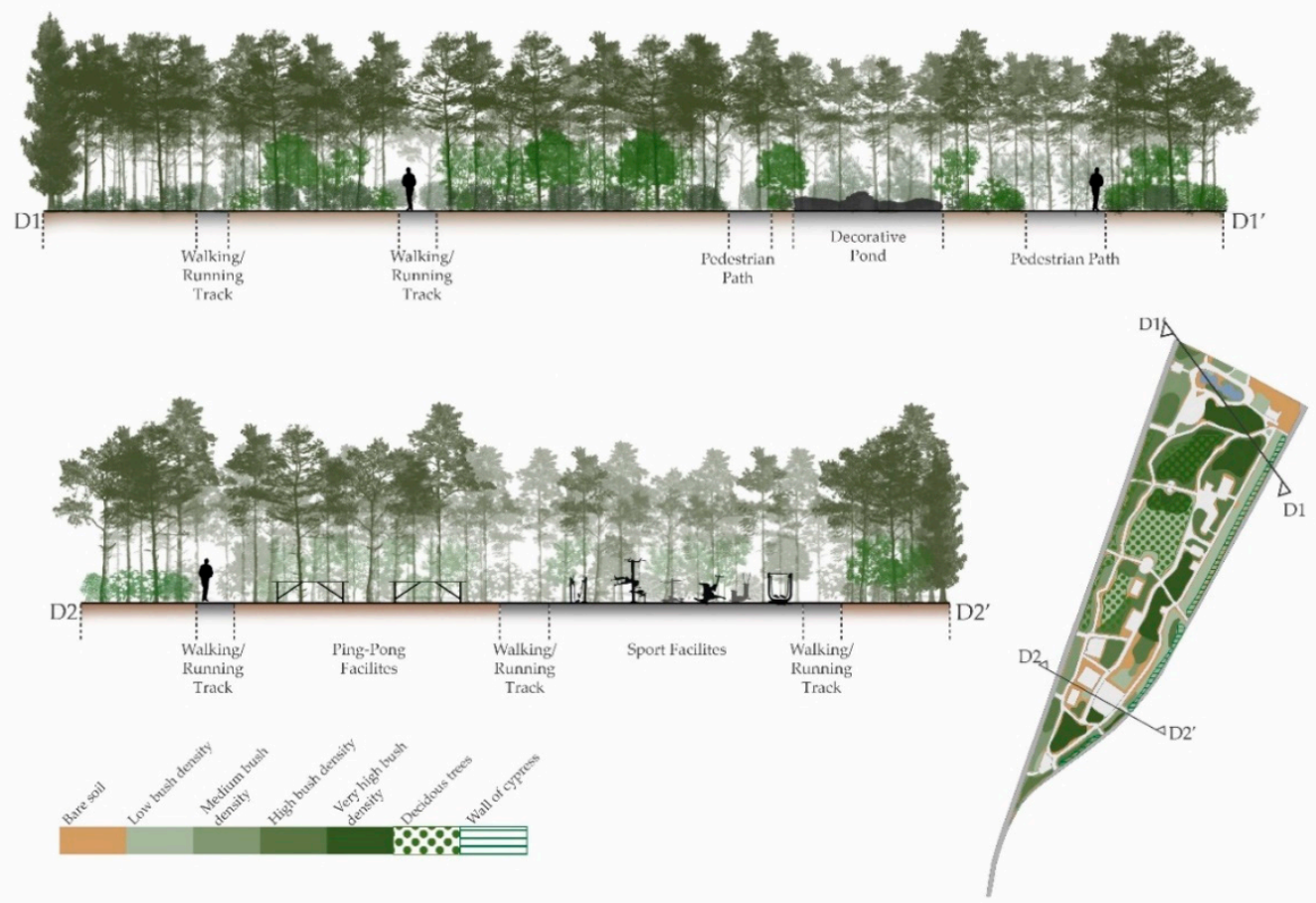

Figure 6. Height and density of trees, bushes, and shrubs in Municipality Park (reproduced by researchers based on the Municipality Base Map [66]).

In regard to the facilities and fixed furniture, the parks house various common urban furniture and sports facilities. Most of the sports facilities are located in Municipality Park, with one such area in the FSM Wood. The walking/running tracks, paved with rubber, mainly run along the main circulation routes of the parks. 
By and large, the parks' sports facilities and areas where seating elements are clustered function as focal points (Figures 7-9). Decorative ponds also create an attraction point with their surrounding seating elements (Figure 9). Most of the circulation lines serve as landscape vistas that consist of tunnel-like views of plantation, especially in Municipality Park due to the vegetation density (Figure 10). Examination of the visibility of the surrounding urban pattern determined that due to the high density of trees, building visibilities are similar in both parks. However, the impacts of nearby roads are higher in the FSM and MAE Woods, as their sparse bushes and shrubs, especially between sidewalks and woods, do not create a strong barrier between the park and the surrounding urban area, and their width does not allow for any great distance from adjacent roads (Figure 11).
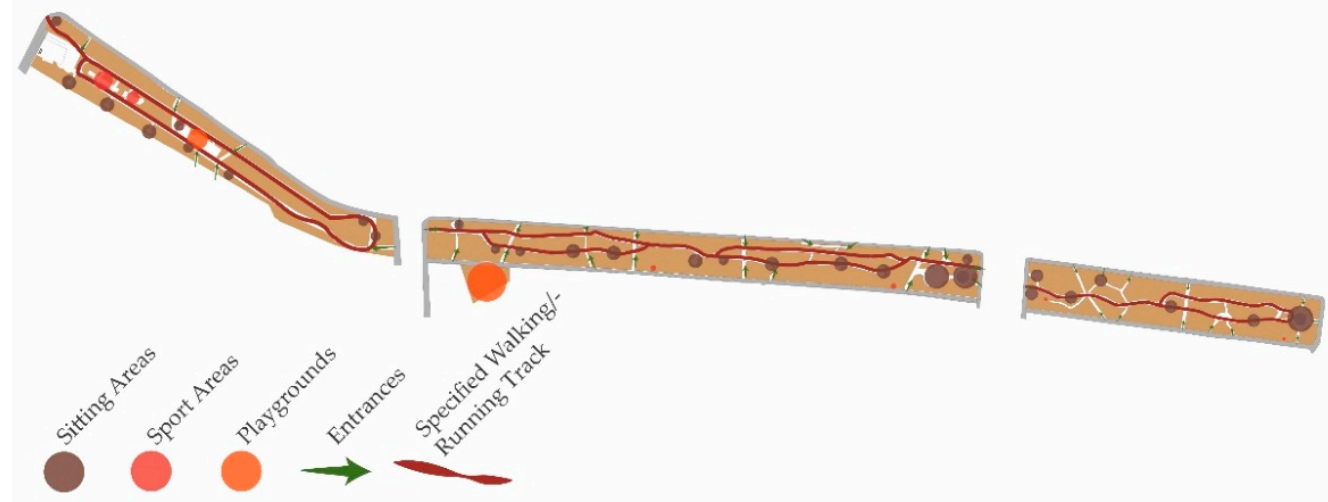

Figure 7. Activity points and axes in the FSM and MAE Woods (reproduced by researchers based on the Municipality Base Map [66]).

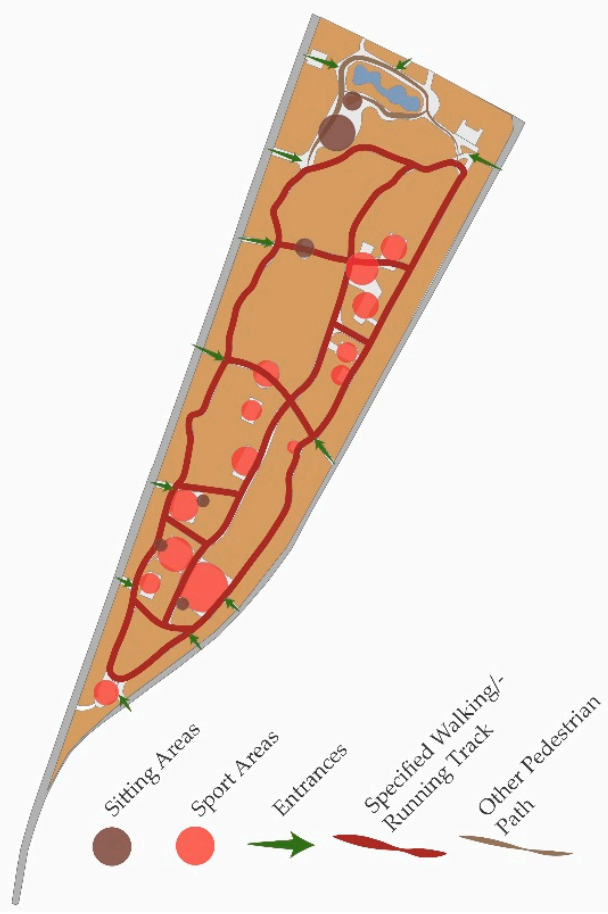

Figure 8. Activity points and axes in Municipality Park (reproduced by researchers based on the Municipality Base Map [66]). 

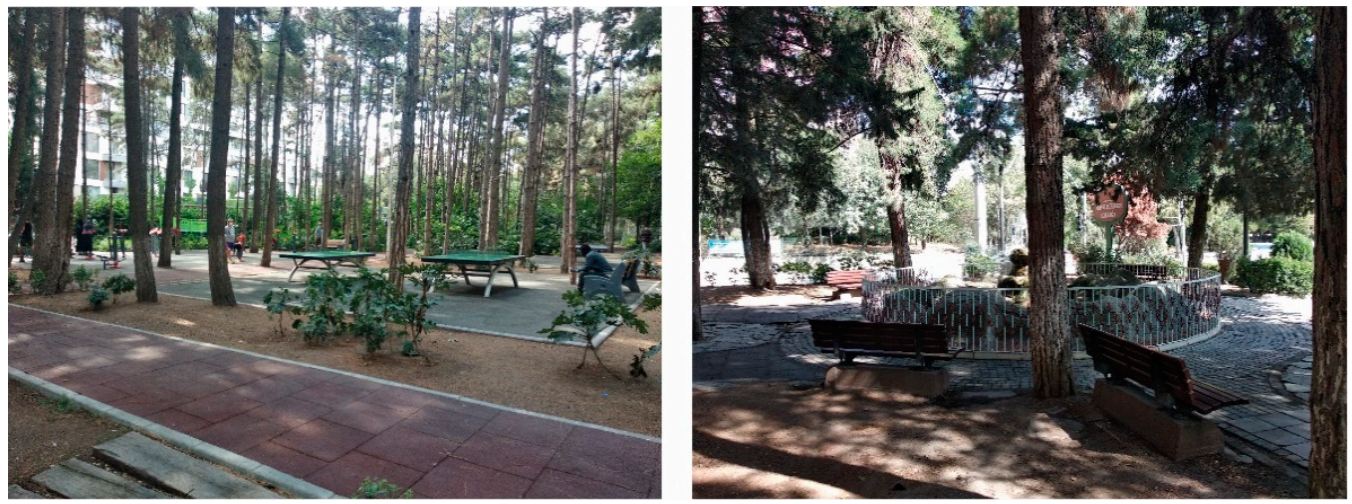

Figure 9. Sports facilities in Municipality Park (left) and pond in the MAE Wood (right).
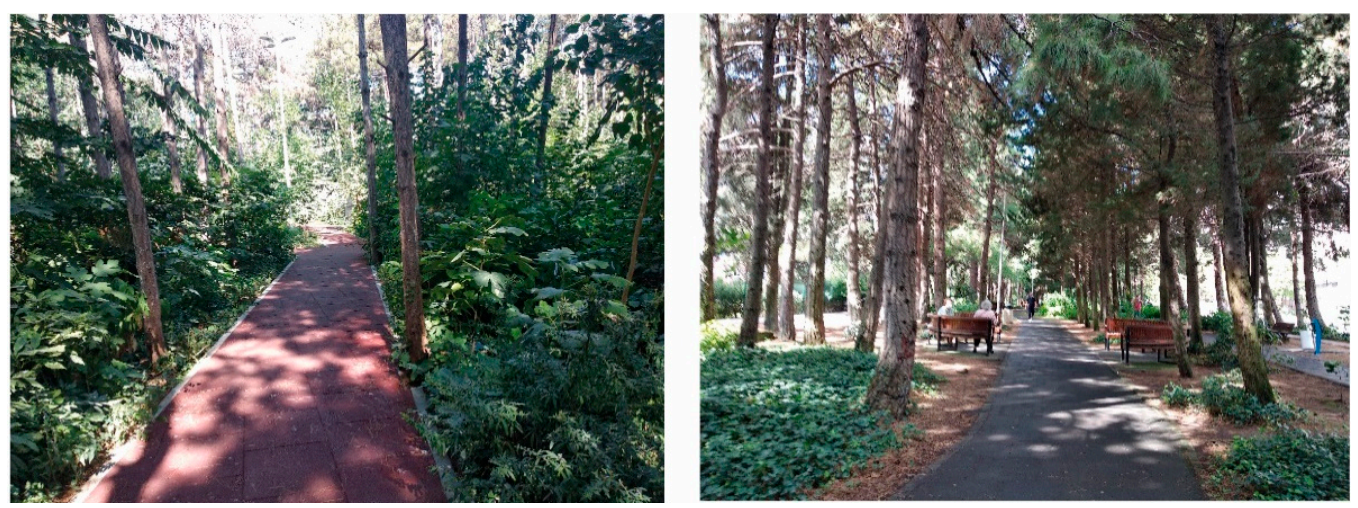

Figure 10. Landscape vistas from Municipality Park (left) and Woods (right).
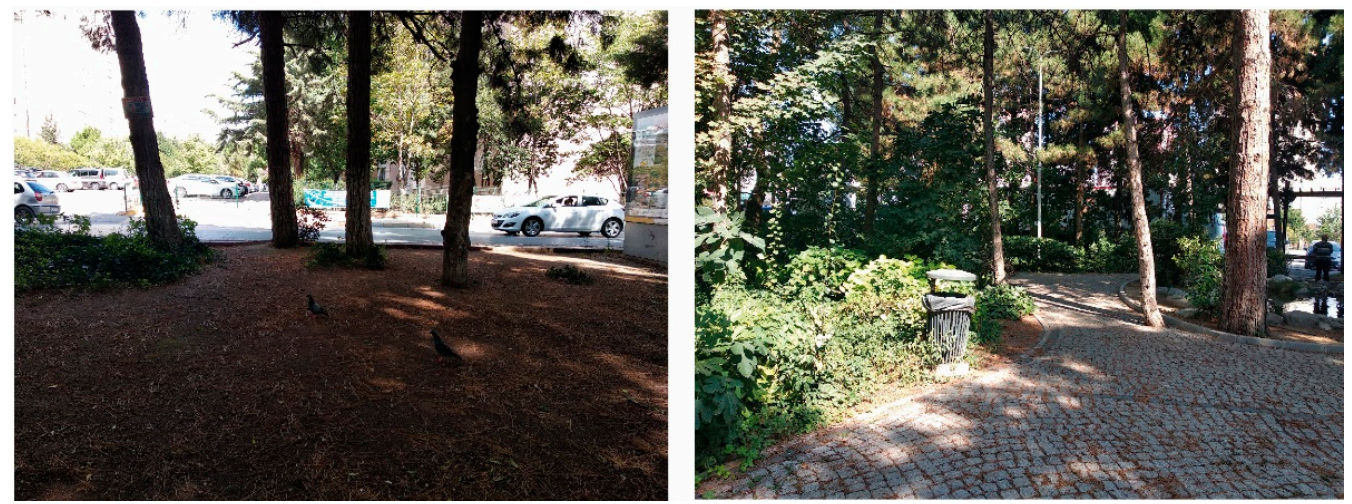

Figure 11. Road visibility from Woods (left) and Municipality Park (right).

Overall, because of its size and shape, Municipality Park has a different structure and characteristics from FSM and MAE Woods, which allows for more plantation and facilitations. On one hand, with its sports facilities and long walking tracks, Municipality Park attracts people who want to be (physically) active. On the other hand, in the Woods, people are mostly passing through or resting, which is expected when its length and shape as a linear park are considered. Moreover, the varying vegetation types and densities of these differently shaped parks affect their exposure to the urban view and the impacts of the adjacent road. These data comprised the base for the investigation of changes in user experience, especially in terms of ecotherapy service.

\section{Findings and Discussion}

The participants from the FSM and MAE Woods consisted of 21 males and 24 females ranging in age from 18 to 75; the participants from Municipality Park consisted of 28 males 
and 17 females ranging in age from 18 to 76 . The average participant age was 42.5 in the Woods and 33.7 in Municipality Park. There were 11 students and 11 retired people in the FSM and MAE Woods' sample, with other participants occupied as medical technician, salesman, beautician, cashier, architect, accountant, teacher and so on. In Municipality Park there were 19 students, with other participants occupying varying professions such as homemaker, retired, machine engineer, biologist, and accountant.

\subsection{Correlations of Connectedness to Nature and Other Scales}

The average CNS scores of each park were almost the same, with 4.1 out of 5 points in the FSM and MAE Woods and 4.06 out of 5 in Municipality Park. User connectedness to nature was thus similar in both parks. Such close CNS values for the two parks demonstrated a constant user profile essential for understanding the relationship between ecotherapy service and park features.

A Spearman's rho correlation analysis for each park was conducted in SPSS among all scales of the survey study, such as the time (A) and frequency (B) of park usage, the number of activities conducted in these parks (C), impacts of design characteristics on park preference (closeness to home, size, physical environment, facilities and furniture and vegetation) (D), satisfaction with design characteristics (E), the impacts of natural elements (F) and urban texture on the park's natural appearance $(\mathrm{G})$, and emotions/mental states $(\mathrm{H})$ related to ecotherapy service. The results of the survey demonstrated a moderate correlation between CNS and the variable frequency of park usage $(B)\left(r_{s}=0.470, p<0.05\right)$, number of activities conducted in the parks $(C)\left(r_{\mathrm{S}}=0.473, p<0.01\right)$, impacts of design characteristics on park preference (D) $\left(r_{\mathrm{s}}=0.419, p<0.01\right)$, impacts of natural elements on the park's natural appearance $(\mathrm{F})\left(\mathrm{r}_{\mathrm{s}}=0.404, p<0.01\right)$ and emotions / mental state $(\mathrm{H})$ $\left(r_{\mathrm{s}}=0.550, p<0.01\right)$. As seen above, it was clear that the CNS score of the participant was moderately related to certain features of the park. In Municipality Park, only satisfaction with design characteristics and emotions / mental states were significant; however, they displayed shallow correlation values $\left(r_{\mathrm{S}}=0.376, p<0.05\right.$ and $\left.r_{\mathrm{S}}=0.386, p<0.01\right)$. Because of the bidirectional relationship between emotional/mental states and CNS score, it was unclear whether those more connected to nature receiveed slightly higher ecotherapy services, or those receiving greater ecotherapy services had an increased connection to nature. However, the data proved a clear relationship between the ecotherapy service and connectedness to nature, which the ecopsychology approach has put forward as a solution to the problem of separation from nature in the urban space.

Besides CNS, another correlation analysis was conducted to reveal the relationship between other scales of the survey. For the FSM and MAE Woods, the frequency of use increased with the age of the participants $\left(r_{S}=0.452, p<0.01\right)$, the years of service $\left(r_{\mathrm{s}}=0.506, p<0.01\right)$, and the effect of park features such as closeness to home, size, physical environment, facilities and furniture and vegetation, on park choice $\left(r_{s}=0.449, p<0.01\right)$. However, it also detected a negative correlation $\left(\mathrm{r}_{\mathrm{s}}=-0.530, p<0.01\right)$ between the number of activities the participants performed and their satisfaction with the suitability of the park for these activities, when the number of participant activities increased, their satisfaction decreased. This result, however, was to be expected upon consideration of the limited facilities in the FSM and MAE Woods. Lastly, emotional services were correlated with participant years of use $\left(r_{\mathrm{s}}=0.309, p<0.05\right)$, their age $\left(\mathrm{r}_{\mathrm{S}}=0.409, p<0.01\right)$ and satisfaction with design characteristics $\left(r_{\mathrm{s}}=0.450, p<0.01\right)$. For Municipality Park, frequency of use correlated solely with the impact of park features on park choice $\left(\mathrm{r}_{\mathrm{s}}=0.396, p<0.01\right)$. Moreover, the emotional experience related to ecotherapy service within the park correlated with the CNS score $\left(r_{\mathrm{s}}=0.386, p<001\right)$ and satisfaction with the interior characteristics of the park $\left(\mathrm{r}_{\mathrm{s}}=0.539, p<0.01\right)$.

These results revealed that users who preferred either park due to factors such as proximity to home, size, and adequacy and compatibility of equipment were using them more frequently. Therefore, in cases where frequent use is intended, parks should be designed in such a way that they are accessible and suitable in size for users, with appropriate facilities, 
ideally tuned physical environmental conditions, and adequate planting. Moreover, because the negative correlation between number of activities and park satisfaction in the FSM and MAE Woods was not observed in Municipality Park, the former can be assumed to provide more limited opportunities for therapeutic activities than the latter.

\subsection{Park Usage and Ecotherapeutic Activities}

The survey put out more descriptive results in addition to the correlation analysis of the scales. Participants were first asked if they used another park anywhere in the city and, if so, what the purpose of that use was. The survey also inquired whether there were other places in İstanbul that made them feel more connected to and integrated with nature and, if so, the reasons for these feelings. A total of $79 \%$ of the participants preferred the parks in the Beylikdüzü District, while $21 \%$ preferred parks located mostly along the Bosporus coasts for their social activities and spaces, sports activities, and walking pathways; others preferred these parks for their natural appearance, vegetation density, available grass for sitting, and closeness to home or work. The concentration of the selected parks in the Beylikdüzü District showed the importance of proximity in park preference. Moreover, social and sports activities and natural appearance were essential criteria in park preference.

Affirmative answers to the second question about the places where participants feel truly in nature and integrated with nature demonstrated an expected preference for the natural areas of Istanbul over the inner city parks; the reasons most often given included natural characteristics of these areas (58\%), such as natural appearance, tree and vegetation density, natural landscapes such as sea and rural views, as well as emotional responses $(43 \%)$ such as satisfaction with the quiet, peacefulness, and being away from the city. While the presence of people, social activities, and sports were essential criteria for park usage; the presence of people and the visibility of urban patterns were negative factors in the feeling of connectedness to nature, and green areas were not enough to provide this feeling in their current state. Responses about the types of preferred areas and the reasons for such preferences corresponded to findings in ecotherapy literature, which indicated that these features should be evaluated in design decisions in order to increase the natural appearance and therapy service of urban parks.

Participants were also asked whether they would engage in 15 given activities (see Figure 12) in these parks, nine of which fell under the working in/with nature group, and five of which were taken from the experiencing nature group. Additionally, the survey inquired, on a 5-point Likert scale, about the level of sufficiency of the park for these activities. In the FSM and MAE Woods, the most frequent activities were sitting/resting for a short time, sitting, walking, and passing through. The park's highest suitability rating (mean value) was for passing through, sitting, and walking (Figure 12). In Municipality Park, the most frequent activities were sports, walking, sitting, sitting/resting for a short time, and passing through. The highest sufficiency ratings belonged to passing through and running (Figure 12). The average number of activities was close in both parks; however, the parks differed in terms of activity groups. While the number of participants choosing activities in the experiencing nature group was similar in both parks, 27 more participants chose activities in the working in/with nature group in the Municipality Park because of the sports facilities located on the site. Consequently, users of Municipality Park spent their time more actively than those of the FSM and MAE Woods. These results indicated that the provision of such sports spaces and equipment can encourage people to be active. 


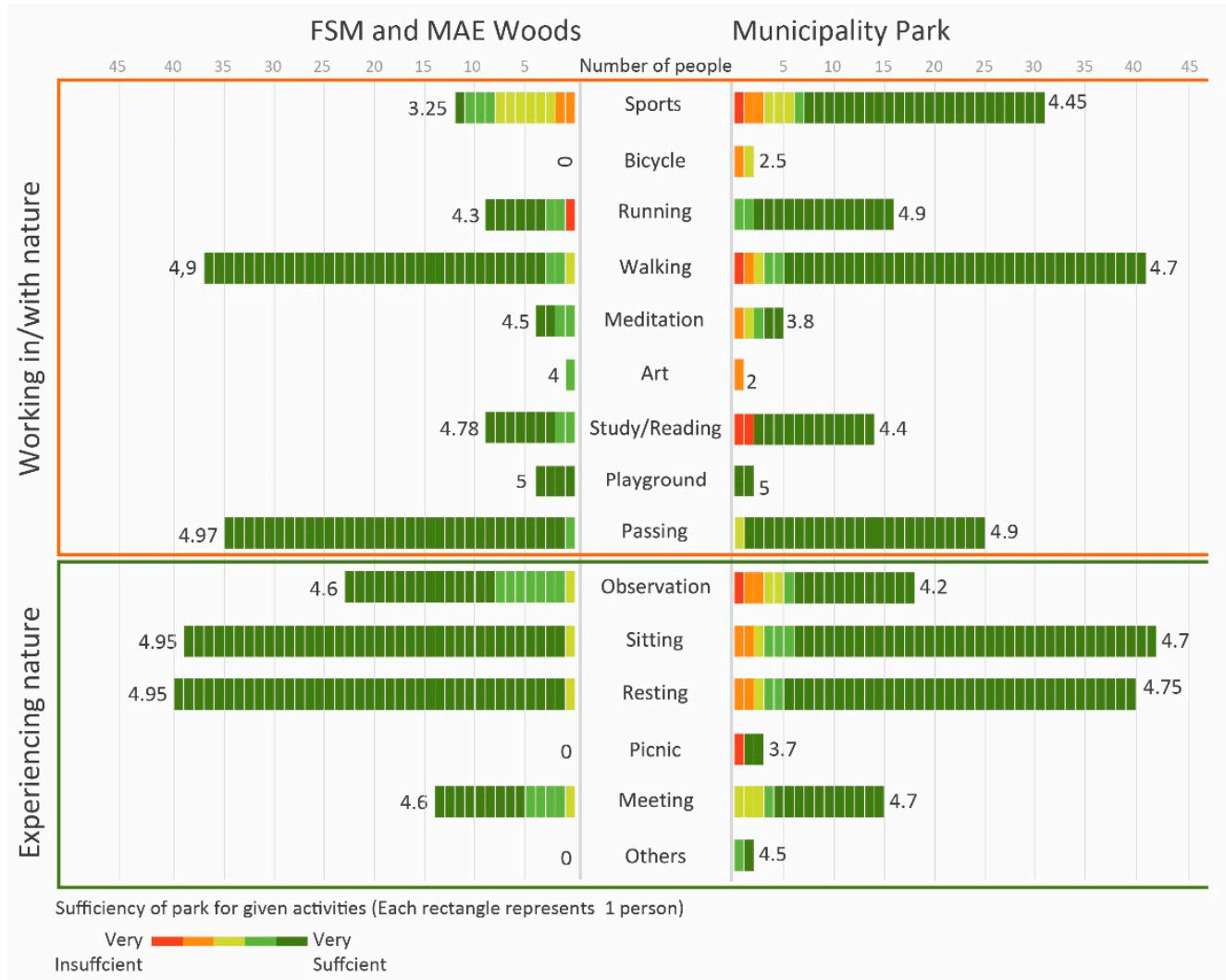

Figure 12. Comparison of ecotherapeutic activities in the FSM and MAE Woods and Municipality Park (number of people and mean values of satisfaction).

\subsection{Park Characteristics, Image of Naturalness and Ecotherapeutic Experiences}

Analysis of the impacts of park features on the park preferences of participants indicated that "closeness to home" had the lowest value for each park, with a mean score of 4.1 points. However, while the scores of Municipality Park were higher than those of the Woods in the categories of sufficient size for use, adequate physical environment (sunlight, fresh air, etc.), and sufficient vegetation, they were lower in the categories of sufficient facilities and furniture value (Figure 13). The findings indicated that both parks were similar in terms of preference due to their closeness to users' homes. However, size, physical environment, and vegetation had a greater impact on a preference for Municipality Park. Still, its sports equipment and furniture were evaluated as insufficient compared to that of the FSM and MAE Woods. It was expected that users of FSM and MAE Woods would be satisfied by the numerous seating elements, but the number of facilities and furniture, consisting of mostly sports equipment and a few seating elements, were not sufficient for users in Municipality Park.

Inquiries concerning the interior characteristics and appearance of the parks attempted to gauge participants' ease of mobility and finding their bearings, ability to be alone and in nature and feel distant from the urban center, and the sufficiency and suitability of facilities, furniture, pavements, and water elements. The results indicated that FSM and MAE Woods had higher scores than Municipality Park for all statements, with the exception of "I feel away from urban area" (Figure 14). Moreover, the results of the "I feel away from urban area" statement demonstrated that both parks were affected by the urban pattern. However, this impact was higher in the FSM and MAE Woods. 


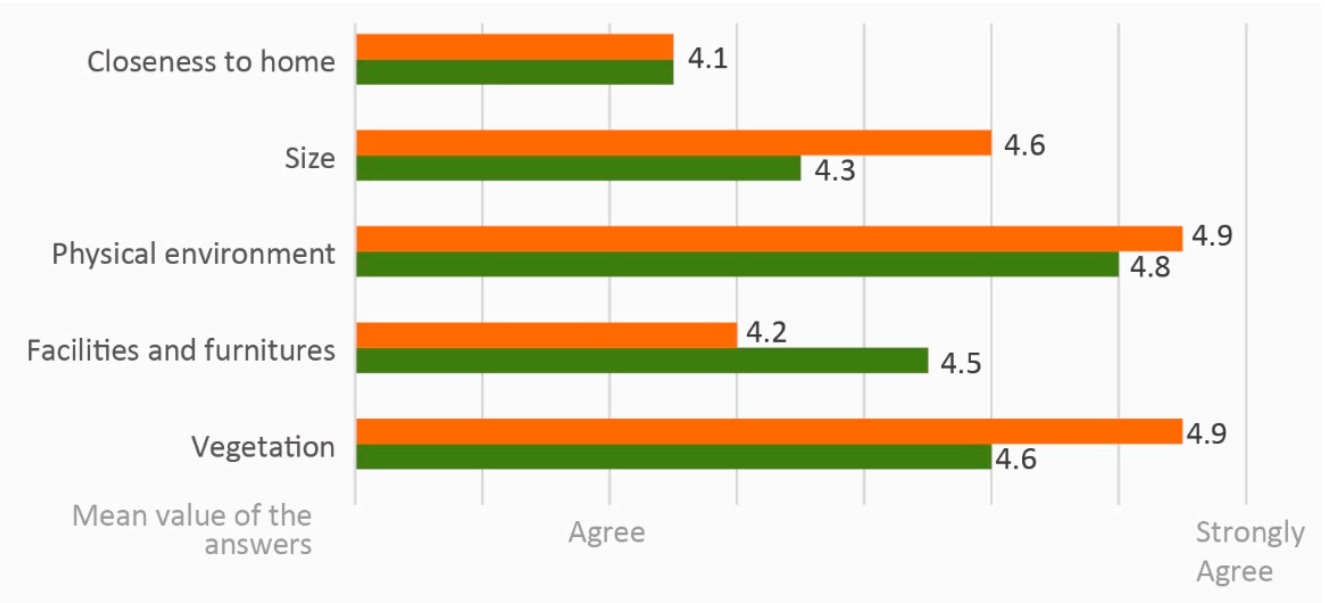

- Municipality Park

- FSM and MAE Woods

Figure 13. Impact of park features on user preference scores (mean values).

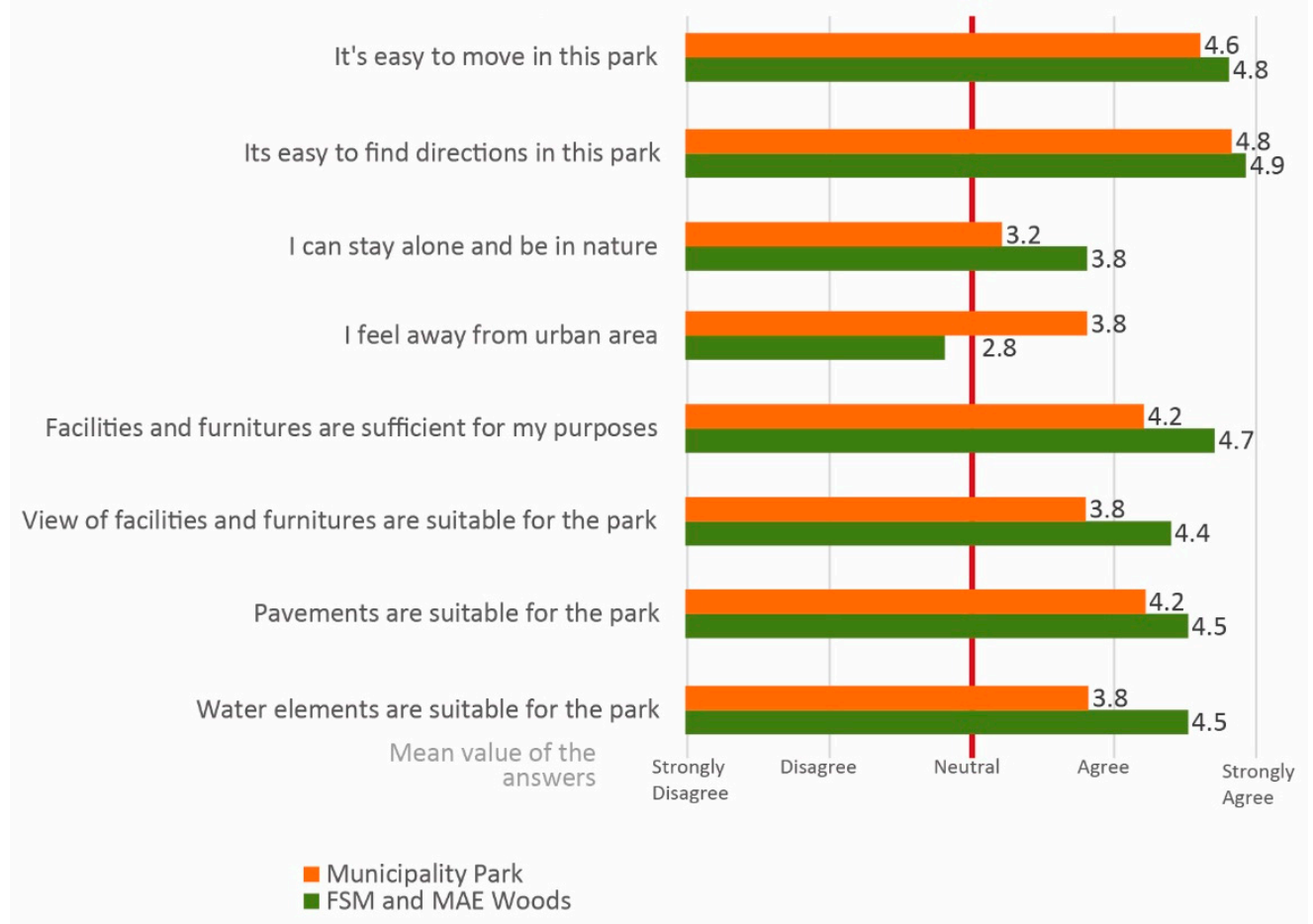

Figure 14. Satisfaction with interior characteristics and appearance (the red line indicates the neutral score of the Likert scale, the threshold of satisfaction and dissatisfaction).

In addition to these statements, participants were asked two open-ended questions, the first of which concerned the elements that might interrupt the natural appearance of the parks (Figure 15). The answers revealed that $80 \%$ of the park users thought that there was nothing interrupting the natural appearance of both parks. However, others responded that, in both parks, certain facilities and furniture were not compatible with the parks' natural appearance. 


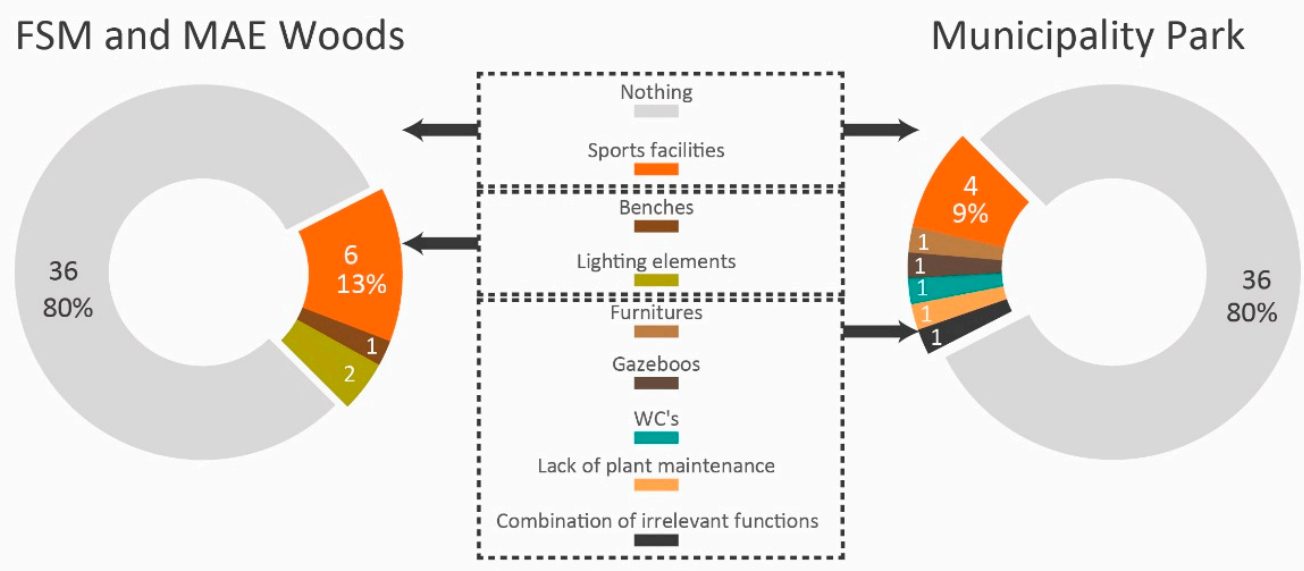

Figure 15. Answers to the question "What are the inner features that interrupt the natural appearance of the park?" (number of people and percentage).

The second open-ended question concerned the exterior factors that interrupted the parks' natural appearance. In Municipality Park, 21 (47\%) participants responded "nothing". However, others mentioned factors such as crowds, building visibility, noise from the roads, garbage, and dust. In the FSM and MAE Woods, 32 (71\%) people mentioned noise from the roads. A total of $20 \%$ of participants also gave answers such as building visibility, garbage, crowds, car visibility, and lack of maintenance (Figure 16). These answers indicated that most of the negative factors were similar in both parks; however, noise from the roads was a severe problem in the FSM and MAE Woods. Additionally, a juxtaposition of the third and fourth statements of the previous question (Figure 14), which referred to the feeling of being "in nature", with the answers of the two open-ended questions aided in understanding the relationship between the feeling of being "in nature" and the interior and exterior features that respondents felt interrupted the parks' natural appearance. Of the 32 people, 25 who gave three or fewer points to the third (I can stay alone and be in nature) and/or fourth (I feel away from urban area) statements also mentioned an interior element and/or exterior factor that broke the natural appearance of Municipality Park (Figure 17); 30 of 34 respondents in the FSM and MAE Woods did the same. These findings demonstrated that the parks' interior elements and exterior factors affected the feeling of being in nature and the natural appearance of the parks and should be evaluated in the design process.

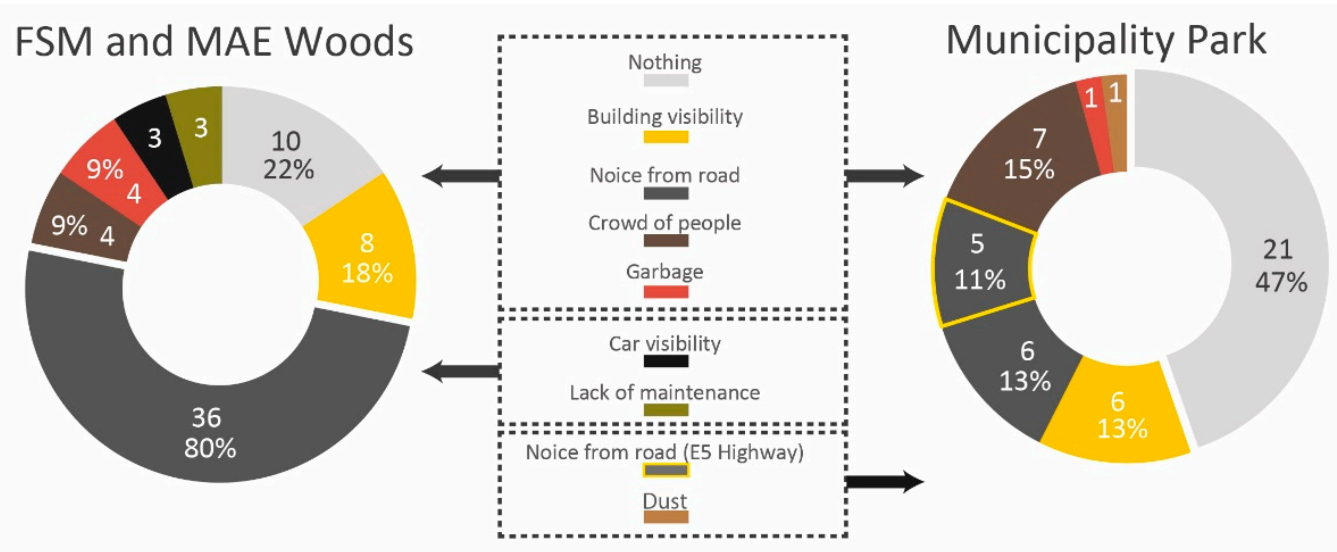

Figure 16. Answers to the question "What are the exterior factors that interrupt the natural appearance of the park?" (number of people and percentage). 
FSM and MAE Woods

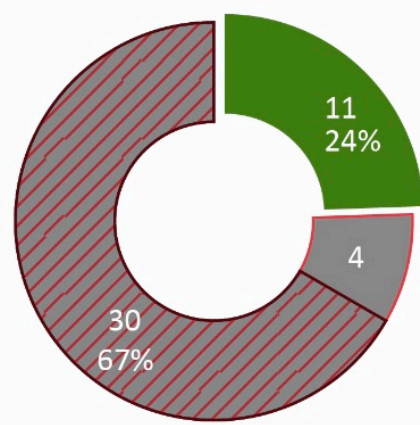

Answers of 3rd and 4th statements

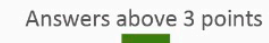

Answers 3 or belove 3 points

People mentioned about an inner and/or outer impact ख
Municipality Park

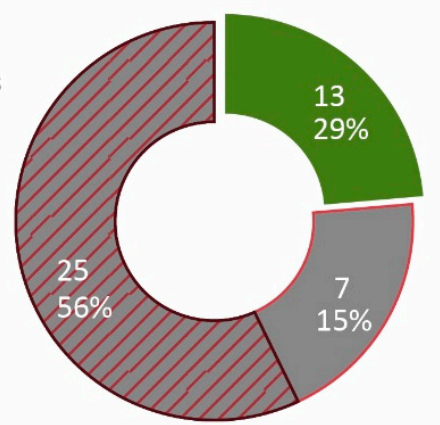

Figure 17. Ratio of people who gave a 3 or below score to the third (I can stay alone and be in nature) and/or fourth (I feel away from urban area) statements and also mentioned an inner and/or outer negative impact on the natural appearance of the park.

The other part of the survey study included seven statements about the impacts of vegetation, one statement on the effect of the amount of paved surfaces in the parks, and three statements about the effects of the urban pattern on the parks' natural appearance. Both parks had almost equal mean scores in the first four questions (Figure 18). However, while participants in the FSM and MAE Woods recorded higher positive views on the effects of the presence of bushes and shrubs on the park's natural appearance, those in Municipality Park responded that the impact of the volume and order (wild-like) of bushes and shrubs had a positive effect on the park's association with nature. Based on similarities in the parks' vegetation types and order and the number of trees shown in the spatial analyses, the two parks had similar values for the impact of these elements on their natural appearance. However, considering the difference in bush and shrub density in the parks, high values were expected for the impact of bushes and shrubs on the natural appearance of Municipality Park, which has a higher density of this type of vegetation.

The questions about the impact of the urban pattern concerned the effects of building visibility, the number of building floors, and road noise and car visibility. The impacts of building visibility and number of floors had slightly higher values in Municipality Park, while the impacts of road noise and car visibility had higher values in the FSM and MAE Woods (Figure 18). Both parks were similar in the perceived impacts of building visibility; however, the FSM and MAE Woods were more affected by the surrounding roads. Considering the similarities in the surrounding urban pattern for both parks, the reason for this difference may lie in the parks' vegetation. Both parks have a similar tree pattern, consisting of pine trees with bare stems and high crowns that function to block the view of surrounding buildings; nevertheless, they do not diminish park goers' views of adjacent roads. The two parks, however, vary significantly in shrub density. Municipality Park, which is adjacent to a highway, received a lower score than the FSM and MAE Woods because of its dense bush and shrub vegetation, which served to better block the view of the road. This difference indicated that the presence of vegetation contributed to the perception of naturalness by acting as a visual barrier separating the park from the city. 


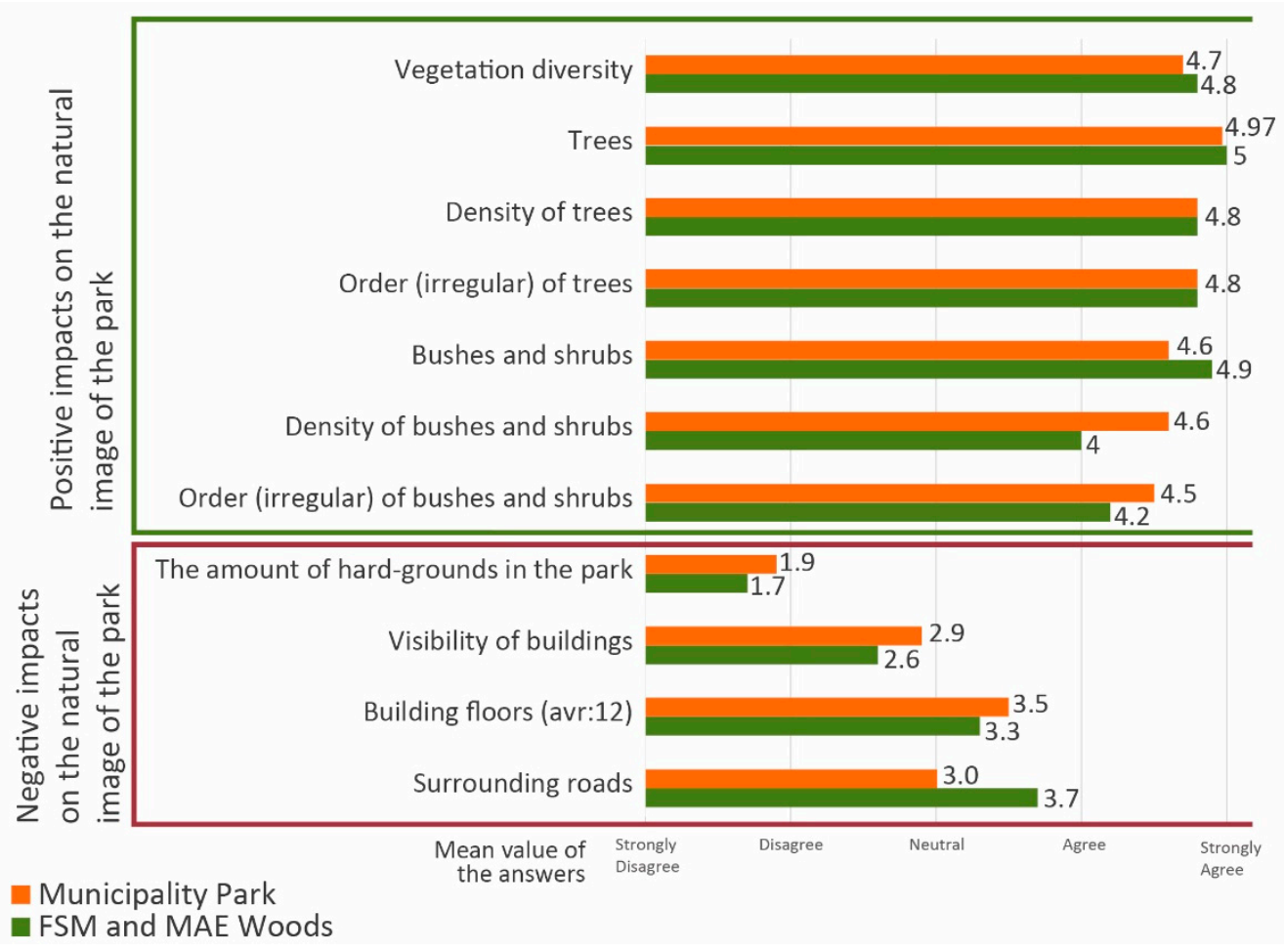

Figure 18. Impacts of the vegetation, paved surfaces, and urban pattern on nature-like appearance of parks (mean values).

After this evaluation of urban impact, participants were asked to point out which parts of the park seemed more natural than others and the reasons for their opinion. In the FSM and MAE Woods $72 \%$ made their selection for reasons related to vegetation and natural characteristics, $13 \%$ for atmosphere (quiet, silent, isolated), and a few for reasons related to water elements and design. In Municipality Park, 29 (64\%) people selected the inner part of the park and the middle walking track due to the density and variety of vegetation, forest-like and wild-like views, quiet environment, and low building visibility. A total of $79 \%$ of the answers were related to vegetation and natural characteristics, while others were based on water elements, emotions, and design. These answers were in line with the literature concerning the features of ecotherapeutic environments, including vegetation density, water elements, and feelings such as quiet, isolation, silence and the urban visibility for both parks. Based on this concordance, it was clear that both parks have elements and features that provide ecotherapy service.

Participants were then asked to point out the part of the parks they liked the most. In FSM and MAE Woods, 15 (33\%) people selected the MAE Wood due to its dense vegetation, size, and the breezy, isolated, and quiet environment. Moreover, the ponds (due to the dense vegetation and sound of water), sports facilities in FSM Woods and the whole park system (due to the length of the park, which allows long walking) were indicated by some other participants. In Municipality Park, 13 people (29\%) selected the sports facilities and the park's quiet, breezy and open environment. Eight selected the northern inner part due to its vegetation density and quiet atmosphere, and five chose the northern sports facilities for their quiet, breezy, and open atmosphere.

Analysis of the answers to these two questions indicated no severe shift between the responses for the first and second questions in the FSM and MAE Woods (Figure 19). Most of the selected parts remained the same in both questions for similar reasons. However, in Municipality Park, there was a contrast between the parts that people saw as more natural and the parts they liked, the principal cause of which was the park's sports facilities and activities (Figure 19). These results indicated that the FSM and MAE Woods were favored 
for their natural characteristics and comfortable environment. However, Municipality Park has different features that provide more than just natural views. Moreover, because of the importance of exercise for both a healthy lifestyle and ecotherapy service, this park has the potential to offer more varied ecotherapeutic activities. All these results were in line with the previous ones regarding park preference, which indicated that Municipality Park stood out because of its available sports activities, illustrating the critical role of facilities that provide opportunities for these activities in park preference and enjoyment.

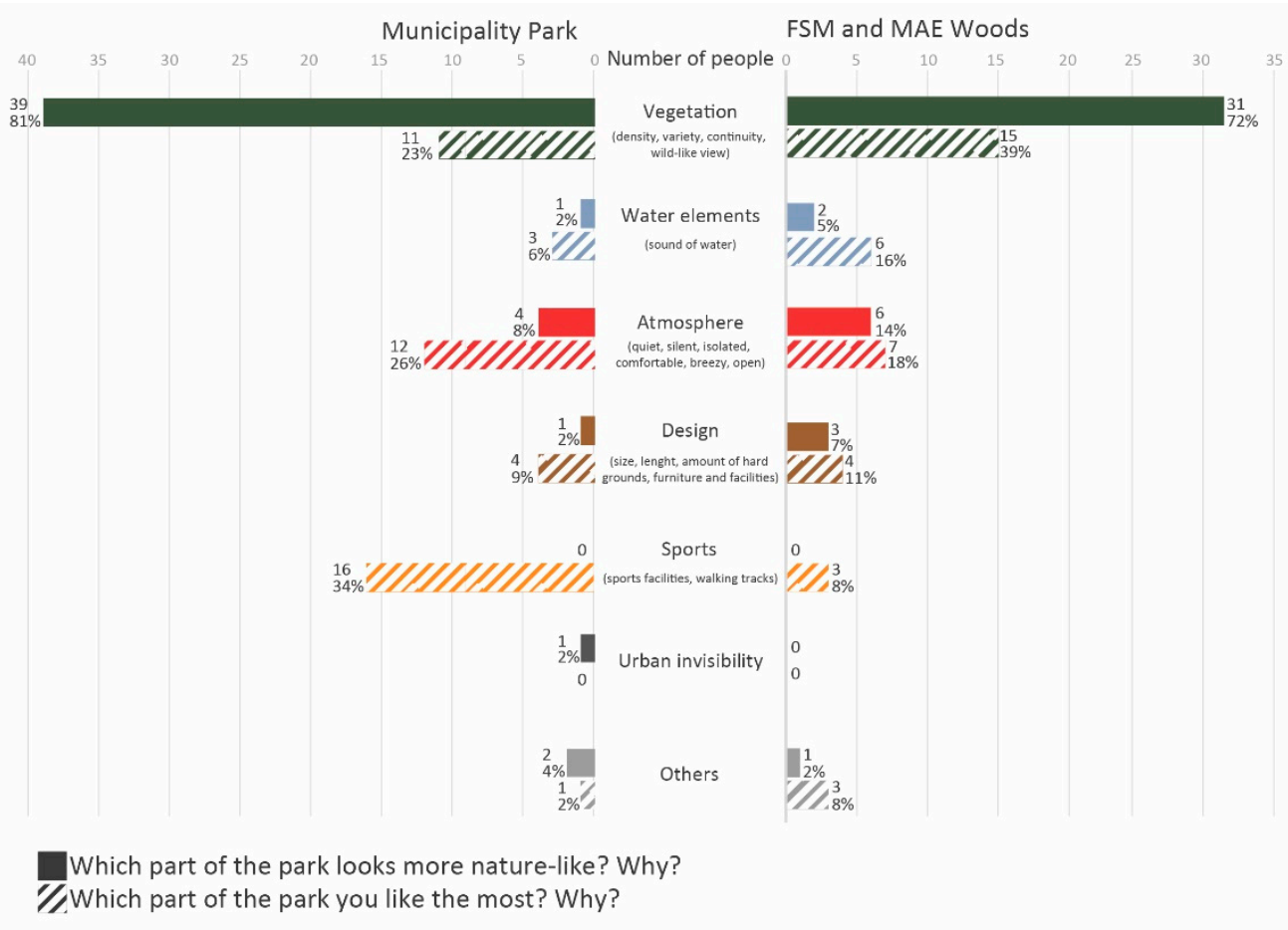

Figure 19. Themes for why respondents preferred different parts of the parks and which ones they regarded as more nature-like.

Finally, participants were asked about the shift in their emotions and mental states when they spent time in the parks. All of the participants confirmed that spending time in these parks improved their mental status. While the differences were small, the values of Municipality Park were found to be slightly higher (Figure 20). These results can be interpreted as both parks being capable of providing an environment where users could experience emotions related to ecotherapy.

In addition to the evaluations, several participants commented on their wishes or mental situations without being asked. These comments were valuable due to the presence of such sentiments in the ecopsychology and ecotherapy studies about the effects of ecotherapy on mental states and emotions.

- My self-esteem increases when I spend time here (FSM).

- $\quad$ This park is the place where I can ask questions and find answers (MAE).

- I'm discharging (MAE).

- Whenever I feel suffocated, I come here (MAE).

- This park is a therapy area (MAE).

- Parks need to be accessible and ubiquitous (MAE).

- There should be areas like this all over the city (MP).

- I'd love to see animals like squirrels (MP).

- It should look pristine (MP).

- This park is like my home (MP).

- It is much more pleasant and beautiful to exercise in the greenery here than in the indoor fitness hall (MP). 


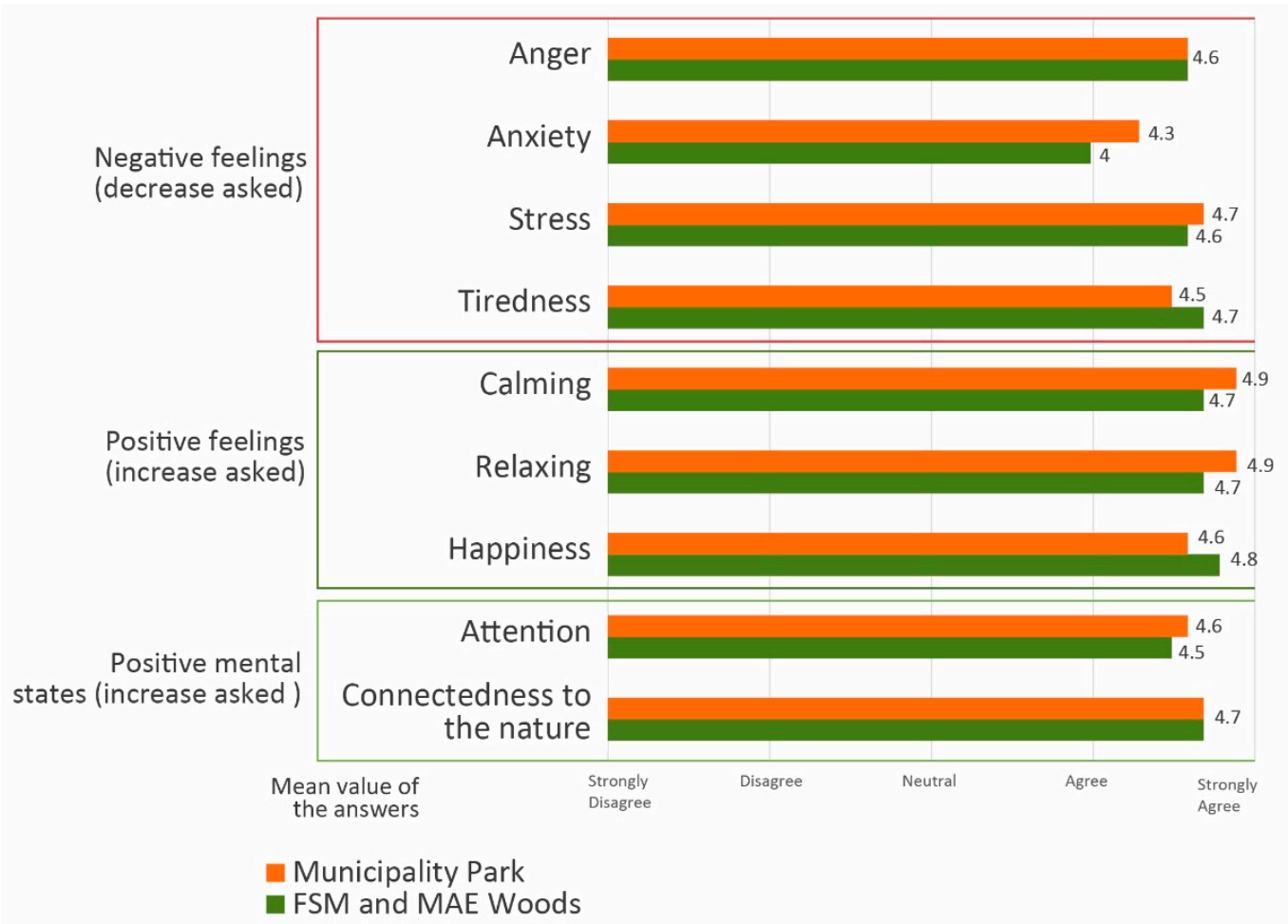

Figure 20. Experience scores of emotions/mental states related to ecotherapy service.

These statements demonstrated that people were experiencing the benefits of ecotherapy service; they also showed the role of the parks' spatial features in providing this service.

\section{Conclusions}

In today's world, many problems have arisen, dependent on the form of urbanization and the nature of urban areas; these problems not only cause environmental problems by affecting natural areas but also negatively affect the health and psychology of citizens in urban areas. The ecopsychology approach, which seeks a solution to these issues in the reestablishment of a relationship with nature, notes the role of the ecotherapy service obtained through spending time in natural areas and defines the main features of therapeutic spaces. As mentioned before, Istanbul lost its valuable natural lands and urban green areas as a result of rapid urban growth and densification that started in 1950s. Besides the loss of natural areas, ecotherapy services cannot be provided in these unplanned and dense urban areas due to the lack of green spaces. In this manner, protecting both natural and urban green areas from uncontrolled and rapid urban growth should be considered due to their immanent values, the ecosystem services they provide and ecotherapy potentials for citizens.

Within the scope of this study, the spatial and functional characteristics of ecotherapy service were evaluated through two parks selected from the Istanbul Metropolitan area. The evaluation was made primarily by comparing the spatial characteristics and user experiences of these two parks with the aim of measuring the effects of different spatial features on experiences and activities related to ecotherapy service, as well as discussing the contributions of the characteristics that can increase the ecotherapy service potential of urban green areas in the urban design processes. The findings of the study parallel the descriptions of therapeutic spaces made by ecopsychology and ecotherapy literature in terms of the effects on the users' connectedness to nature, obtaining therapy services, and the natural perception of parks. The importance of creating more natural landscapes underlined by the ecotherapy literature was demonstrated by the high scores on the experience of emotions/mental states associated with ecotherapy service in both parks. Hence, the ecotherapeutic effect of the space can be increased by creating a dense and wild 
appearance in the urban green areas or by preserving and enriching the existing vegetation as it is. At the same time, both natural features and criteria such as calmness and silence contribute to naturalness and influence the user preferences of the parks. Similarly, findings concerning the effect of different spatial features, the type and appearance of facilities, and the visual and auditory relationship established with the city based on the perception of naturalness show that the therapeutic potential of a park can be increased when these features and relationships are adequately designed. It is possible to obtain more natural, calm, quiet and isolated spaces by using vegetation both to cut off the relationship of the park with the city and to reduce the urban effect, and to separate different functions (sports areas, seating areas, etc.) in the park. In addition to spatial features, the provision of space and equipment for therapeutic activities is influential in the choice and enjoyment of the park while at the same time encouraging people to engage in an active lifestyle.

To conclude, in accordance with the contributions of ecopsychology and ecotherapy studies to design processes, both the physical and psychological health of urban citizens can be increased, and environmental problems may be solved through the transformation of individuals. For further research in this direction, more spatial studies and design examples taken up from this perspective are needed to assess the contributions of the ecopsychology discipline.

Supplementary Materials: The following are available online at https:/ /www.mdpi.com/article/10 .3390/su13094600/s1, Table S1: Survey Form.

Author Contributions: Conceptualization, D.K. and G.D.O.; methodology, D.K. and G.D.O.; software, D.K. and G.D.O.; validation, D.K. and G.D.O.; investigation, D.K. and G.D.O.; resources, D.K. and G.D.O.; data curation, D.K. and G.D.O.; writing-original draft preparation, D.K.; writingreview and editing, G.D.O.; visualization, D.K.; supervision, G.D.O. All authors have read and agreed to the published version of the manuscript.

Funding: This research received no external funding.

Institutional Review Board Statement: Not applicable.

Informed Consent Statement: Informed consent was obtained from all subjects involved in the study.

Data Availability Statement: The data presented in this study are available on request from the corresponding author. The data are not publicly available due to privacy.

Conflicts of Interest: The authors declare no conflict of interest.

Declaration: This work has been presented on Greening cities shaping cities symposium in October 2020, www.greeningcities-shapingcities.polimi.it.

\section{References}

1. Kara, D.; Oruç, G.D. Birey-Doğa İlişkisinin Yeniden Kurgulanması Bağlamında Ekoterapötik Mekânlar. Tasar. Kuram 2020, 16, 257-277. [CrossRef]

2. Singh, R.L.; Singh, P.K. Principles and Applications of Environmental Biotechnology for a Sustainable Future; Singh, R.L., Ed.; Springer: Singapore, 2017; ISBN 978-981-10-1865-7.

3. Flies, E.J.; Mavoa, S.; Zosky, G.R.; Mantzioris, E.; Williams, C.; Eri, R.; Brook, B.W.; Buettel, J.C. Urban-associated diseases: Candidate diseases, environmental risk factors, and a path forward. Environ. Int. 2019, 133, 105187. [CrossRef] [PubMed]

4. Jackson, L.E. The relationship of urban design to human health and condition. Landsc. Urban Plan. 2003, 64, 191-200. [CrossRef]

5. Moore, M.; Gould, P.; Keary, B.S. Global urbanization and impact on health. Int. J. Hyg. Environ. Health 2003, 206, 269-278. [CrossRef] [PubMed]

6. Mutatkar, R. Public health problems of urbanization. Soc. Sci. Med. 1995, 41, 977-981. [CrossRef]

7. Phillips, D. Urbanization and human health. Parasitology 1993, 106, S93-S107. [CrossRef] [PubMed]

8. Weimann, A.; Oni, T. A Systematised Review of the Health Impact of Urban Informal Settlements and Implications for Upgrading Interventions in South Africa, a Rapidly Urbanising Middle-Income Country. Int. J. Environ. Res. Public Health 2019, 16, 3608. [CrossRef] [PubMed]

9. Kumar, P.; Druckman, A.; Gallagher, J.; Gatersleben, B.; Allison, S.; Eisenman, T.S.; Hoang, U.; Hama, S.; Tiwari, A.; Sharma, A.; et al. The nexus between air pollution, green infrastructure and human health. Environ. Int. $2019,133,105181$. [CrossRef] [PubMed] 
10. Restivo, V.; Cernigliaro, A.; Casuccio, A. Urban Sprawl and Health Outcome Associations in Sicily. Int. J. Environ. Res. Public Health 2019, 16, 1350. [CrossRef] [PubMed]

11. Qiu, Y.; Liu, Y.; Liu, Y.; Li, Z. Exploring the Linkage between the Neighborhood Environment and Mental Health in Guangzhou, China. Int. J. Environ. Res. Public Health 2019, 16, 3206. [CrossRef] [PubMed]

12. Bhugra, D.; Castaldelli-Maia, J.M.; Torales, J.; Ventriglio, A. Megacities, migration, and mental health. Lancet Psychiatry 2019, 6, 884-885. [CrossRef]

13. Reichert, M.; Braun, U.; Lautenbach, S.; Zipf, A.; Ebner-Priemer, U.; Tost, H.; Meyer-Lindenberg, A. Studying the impact of built environments on human mental health in everyday life: Methodological developments, state-of-the-art and technological frontiers. Curr. Opin. Psychol. 2020, 32, 158-164. [CrossRef]

14. Steg, L.; Van den Berg, A.E.; de Groot, J.I.M. Environmental Psychology: An Introduction, 2nd ed.; Steg, L., de Groot, J.I.M., Eds.; BPS textbooks in psychology; Wiley-Blackwell: Hoboken, NJ, USA, 2018; ISBN 978-1-119-24111-9.

15. Rozsak, T. Voice of the Earth: An Exploration of Ecopsychology; Simon \& Schuster: New York, NY, USA, 1992; ISBN 0-671-72968-3.

16. Scull, J. Ecopsychology: Where Does It Fit in Psychology in 2009? Trumpeter J. Ecosophy. 2008, $24,18$.

17. Clinebell, H. Ecotherapy: Healing Ourselves, Healing the Earth, 1st ed.; Routledge: London, UK, 2013; ISBN 978-1-315-79977-3.

18. Wheeling, S.D. Making Sense. West Va. Med. J. 1993, 89, 113.

19. Haase, D.; Larondelle, N.; Andersson, E.; Artmann, M.; Borgström, S.; Breuste, J.; Gomez-Baggethun, E.; Gren, Å.; Hamstead, Z.; Hansen, R.; et al. A Quantitative Review of Urban Ecosystem Service Assessments: Concepts, Models, and Implementation. Ambio 2014, 43, 413-433. [CrossRef]

20. Parker, J.; De Baro, M.E.Z. Green Infrastructure in the Urban Environment: A Systematic Quantitative Review. Sustainability 2019, 11, 3182. [CrossRef]

21. Qin, B.; Zhu, W.; Wang, J.; Peng, Y. Understanding the relationship between neighbourhood green space and mental wellbeing: A case study of Beijing, China. Cities 2021, 109, 103039. [CrossRef]

22. Triguero-Mas, M.; Dadvand, P.; Cirach, M.; Martínez, D.; Medina, A.; Mompart, A.; Basagaña, X.; Gražulevičienè, R.; Nieuwenhuijsen, M.J. Natural outdoor environments and mental and physical health: Relationships and mechanisms. Environ. Int. 2015, 77, 35-41. [CrossRef]

23. Summers, J.K.; Vivian, D.N. Ecotherapy-A Forgotten Ecosystem Service: A Review. Front. Psychol. 2018, 9, 1389. [CrossRef] [PubMed]

24. Wilson, N.; Ross, M.; Lafferty, K.; Jones, R. A review of ecotherapy as an adjunct form of treatment for those who use mental health services. J. Public Ment. Health 2009, 7, 23-35. [CrossRef]

25. Sackett, C.R. Ecotherapy: A Counter to Society's Unhealthy Trend? J. Creat. Ment. Health 2010, 5, 134-141. [CrossRef]

26. Schebella, M.F.; Weber, D.; Lindsey, K.; Daniels, C.B. For the Love of Nature: Exploring the Importance of Species Diversity and Micro-Variables Associated with Favorite Outdoor Places. Front. Psychol. 2017, 8, 2094. [CrossRef] [PubMed]

27. Stevens, P. Embedment in the environment: A new paradigm for well-being? Perspect. Public Health 2010, 130, 265-269. [CrossRef] [PubMed]

28. Kamitsis, I.; Simmonds, J.G. Using Resources of Nature in the Counselling Room: Qualitative Research into Ecotherapy Practice. Int. J. Adv. Couns. 2017, 39, 229-248. [CrossRef]

29. Abdelaal, M.S.; Soebarto, V. Biophilia and Salutogenesis as restorative design approaches in healthcare architecture. Arch. Sci. Rev. 2019, 62, 195-205. [CrossRef]

30. Pasanen, T.; Johnson, K.; Lee, K.; Korpela, K. Can Nature Walks With Psychological Tasks Improve Mood, Self-Reported Restoration, and Sustained Attention? Results from Two Experimental Field Studies. Front. Psychol. 2018, 9, 2057. [CrossRef] [PubMed]

31. Reese, R.F.; Lewis, T.F. Greening Counseling: Examining Multivariate Relationships between Ecowellness and Holistic Wellness. J. Humanist. Couns. 2019, 58, 53-67. [CrossRef]

32. Barnes, M.R.; Donahue, M.L.; Keeler, B.L.; Shorb, C.M.; Mohtadi, T.Z.; Shelby, L.J. Characterizing Nature and Participant Experience in Studies of Nature Exposure for Positive Mental Health: An Integrative Review. Front. Psychol. $2019,9,2617$. [CrossRef] [PubMed]

33. Wolsko, C.; Hoyt, K. Employing the Restorative Capacity of Nature: Pathways to Practicing Ecotherapy among Mental Health Professionals. Ecopsychology 2012, 4, 10-24. [CrossRef]

34. Greenleaf, A.T.; Bryant, R.M.; Pollock, J.B. Nature-Based Counseling: Integrating the Healing Benefits of Nature into Practice. Int. J. Adv. Couns. 2013, 36, 162-174. [CrossRef]

35. Bornioli, A.; Parkhurst, G.; Morgan, P.L. The psychological wellbeing benefits of place engagement during walking in urban environments: A qualitative photo-elicitation study. Health Place 2018, 53, 228-236. [CrossRef]

36. Burls, A. People and green spaces: Promoting public health and mental well-being through ecotherapy. J. Public Ment. Health 2007, 6, 24-39. [CrossRef]

37. Chatalos, P.A. Sustainability: Ecopsychological insights and person-centered contributions. Pers. Exp. Psychother. 2013, 12, 355-367. [CrossRef]

38. Brazier, C. Ecotherapy in Practice: A Buddhist Model; Routledge: London, UK; Taylor \& Francis Group: New York, NY, USA, 2018; ISBN 978-0-415-78595-2. 
39. Wilson, N.; Fleming, S.; Jones, R.; Lafferty, K.; Cathrine, K.; Seaman, P.; Knifton, L. Green shoots of recovery: The impact of a mental health ecotherapy programme. Ment. Health Rev. J. 2010, 15, 4-14. [CrossRef]

40. Davis, K.M.; Atkins, S.S. Ecotherapy: Tribalism in the Mountains and Forest. J. Creat. Ment. Health 2009, 4, 272-282. [CrossRef]

41. Ibes, D.; Hirama, I.; Schuyler, C. Greenspace Ecotherapy Interventions: The Stress-Reduction Potential of Green Micro-Breaks Integrating Nature Connection and Mind-Body Skills. Ecopsychology 2018, 10, 137-150. [CrossRef]

42. Juan, C.S.; Subiza-Pérez, M.; Vozmediano, L. Restoration and the City: The Role of Public Urban Squares. Front. Psychol. 2017, 8, 2093. [CrossRef]

43. Pálsdóttir, A.; Wissler, S.; Nilsson, K.; Petersson, I.F.; Grahn, P. Nature-Based Rehabilitation in Peri-Urban Areas for People with Stress-Related Illnesses-A Controlled Prospective Study. Acta Hortic. 2015, 31-35. [CrossRef]

44. Cole, D.N.; Hall, T.E. Experiencing the Restorative Components of Wilderness Environments: Does Congestion Interfere and Does Length of Exposure Matter? Environ. Behav. 2010, 42, 806-823. [CrossRef]

45. Hartig, T.; Staats, H. Guest Editors' introduction: Restorative environments. J. Environ. Psychol. 2003, 23, 103-107. [CrossRef]

46. Jordan, M.; Marshall, H. Taking counselling and psychotherapy outside: Destruction or enrichment of the therapeutic frame? Eur. J. Psychother. Couns. 2010, 12, 345-359. [CrossRef]

47. Pedersen, E.; Weisner, S.E.; Johansson, M. Wetland areas' direct contributions to residents' well-being entitle them to high cultural ecosystem values. Sci. Total Environ. 2019, 646, 1315-1326. [CrossRef]

48. Clatworthy, J.; Hinds, J.; Camic, P.M. Gardening as a mental health intervention: A review. Ment. Health Rev. J. 2013, 18, 214-225. [CrossRef]

49. Kusmane, A.S.; Ile, U.; Ziemelniece, A. Importance of Trees with Low-growing Branches and Shrubs in Perception of Urban Spaces. IOP Conf. Ser. Mater. Sci. Eng. 2019, 471, 092061. [CrossRef]

50. Stoltz, J.; Schaffer, C. Salutogenic Affordances and Sustainability: Multiple Benefits with Edible Forest Gardens in Urban Green Spaces. Front. Psychol. 2018, 9, 2344. [CrossRef]

51. Grassini, S.; Revonsuo, A.; Castellotti, S.; Petrizzo, I.; Benedetti, V.; Koivisto, M. Processing of natural scenery is associated with lower attentional and cognitive load compared with urban ones. J. Environ. Psychol. 2019, 62, 1-11. [CrossRef]

52. Phelps, C.; Butler, C.; Cousins, A.; Hughes, C. Sowing the seeds or failing to blossom? A feasibility study of a simple ecotherapybased intervention in women affected by breast cancer. Ecancermedicalscience 2015, 9. [CrossRef] [PubMed]

53. Pedretti-Burls, A. Ecotherapy: A Therapeutic and Educative Model. J. Mediterr. Ecol. 2007, 8, $19-25$.

54. Wang, D.; Macmillan, T. The Benefits of Gardening for Older Adults: A Systematic Review of the Literature. Act. Adapt. Aging 2013, 37, 153-181. [CrossRef]

55. Bagot, K.L.; Allen, F.C.L.; Toukhsati, S. Perceived restorativeness of children's school playground environments: Nature, playground features and play period experiences. J. Environ. Psychol. 2015, 41, 1-9. [CrossRef]

56. Hauru, K.; Lehvävirta, S.; Korpela, K.; Kotze, D.J. Closure of view to the urban matrix has positive effects on perceived restorativeness in urban forests in Helsinki, Finland. Landsc. Urban Plan. 2012, 107, 361-369. [CrossRef]

57. Lindal, P.J.; Hartig, T. Architectural variation, building height, and the restorative quality of urban residential streetscapes. J. Environ. Psychol. 2013, 33, 26-36. [CrossRef]

58. Gill, C.; Packer, J.; Ballantyne, R. Spiritual retreats as a restorative destination: Design factors facilitating restorative outcomes. Ann. Tour. Res. 2019, 79, 102761. [CrossRef]

59. Mayer, F.S.; Frantz, C.M. The connectedness to nature scale: A measure of individuals' feeling in community with nature. J. Environ. Psychol. 2004, 24, 503-515. [CrossRef]

60. Austin, E.S.; Leopold, A. A Sand County Almanac with Other Essays on Conservation from Round River. Bird-Banding 1967, 38, 252. [CrossRef]

61. Karakuyu, M.; Tezer, S.T.; Balik, H. İstanbul'un Tarihsel Topoğrafyası ve Literatür Değerlendirmesi. 2010. Available online: https: / / dergipark.org.tr/tr/download/article-file/ 652793 (accessed on 15 March 2021).

62. Tekeli, E.; Kuşuluoğlu, D.; Ersoy, M. Kentleşme ve Yeşil Alan Değişiminde İstanbul Boğaz Köprülerinin Rolü. Anadolu Doğa Bilim. Derg. 2015, 6, 211-219.

63. 2020 Adrese Dayalı Nüfus Kayıt Sistemi Sonuçları. 2021. Available online: https:/ / data.tuik.gov.tr/Bulten/Index?p=AdreseDayali-Nufus-Kayit-Sistemi-Sonuclari-2020-37210 (accessed on 15 April 2021).

64. Keçeli, A.; Sariusta, F.; Karakuyu, M. Kamu Hizmetlerinin Kentsel Yaşanabilirlik Üzerine Etkisi: Beylikdüzü Örneği. Marmara Cograf. Derg. 2014, 29. [CrossRef]

65. Yandex Satellite Image 2018. Available online: https:/ / yandex.com.tr/harita / $107757 /$ beylikduzu/?1l=28.648786\%2C41.007837 $\& z=16.09$ (accessed on 15 December 2020).

66. Beylikdüzü Municipality Municipality Basemap. Available online: https://ebys.beylikduzu.bel.tr/ebelediye (accessed on 15 April 2021).

67. Google Earth Sattelite Image 2020. Available online: https: / / earth.google.com/web/@41.00961869,28.64648813,169.68696015a,13 56.4063303d,35y,0h,0t,0r (accessed on 8 April 2021). 